\title{
RETROACTIVITY AND ADMINISTRATIVE RULEMAKING
}

\author{
WILLIAM V. LUNEBURG*
}

\section{INTRODUCTION}

Retroactivity is no stranger to the judicial process. Historically it has been the norm, given the Blackstonian view of the judge's role as that of "discovering" and applying "the law" rather than creating it." Conversely, prospectivity has been a hallinark of the legislative product. However, in the law-as in life-generalization begets exception. Judges occasionally prospectively overrule judicial precedents, ${ }^{2}$ and at times leg. islatures alter the legal consequences of past transactions and occurrences.

Administrative agencies may make both prospective and retroactive policy because they are vested with quasi-legislative and quasi-adjudicatory powers. The legislative role correlates with prospective adıninistrative pohicymaking and with agency rulemaking functions. The judicial role is evidenced by retrospective policymaking via adjudication. Viewed in this way, a legislative or substantive rule ${ }^{3}$ with a retroactive effect seems anoinalous. In fact, such rules are infrequently proinulgated. Yet some agencies, such as the Departınent of Health and Hunian Services (HHS), have perceived a need for retroactive rules and acted on such a need. 4

* Professor of Law, University of Pittsburgh School of Law. Many individuals took the time to read and offer valuable comments - both substantive and organizational - on earlier drafts, including Michael Asimow, Richard Berg, Arthur Bonfield, Michael Bowers, Clark Byse, George Cohen, Wilham Eskridge, Cyril Fox, Philip Frickey, William Funk, Emest Gellhorn, Walter Gellhorn, Erika Jones, Richard Lazarus, Ronald Levin, Nancy Miller, Sidney Shapiro, and Carl Tobias.

1. See 1 W. Blackstone, Commentaries on the Laws of ENGLand *70-72; Mishkin, Foreword: The High Court, The Great Writ, and the Due Process of Time and Law, 79 HARV. L. REV. 56, 58-60 (1965) (Blackstone's "declaratory theory" of conunon law proposes the general rule that a court applies its rules retroactively).

2. See, e.g., Traynor, Quo Vadis, Prospective Overruling: A Question of Judicial Responsibility, 28 HAST. L.J. 533, 548 (1977) (discussing prospective overruling of judicial precedents, and notiug that the choice between prospective and retroactive application "calls for the most sensitive balancing of competing clainis to justice").

3. A legislative rule is an agency statement that has the legal effect of a statute passed by Congress. See Administrative Procedure Act, 5 U.S.C. $\$ 551$ (1988). An interpretative rule may be granted judicial deference without formal binding effect. See id. §553(b)(3)(a). See generally $R$. Pierce, S. Shapiro, \& P. Verkuil, Administrative Law and Process 308 (1985).

4. See infra text accompanying notes 110-22, 265-67. 
During its 1988-89 Term, the Supreme Court considered, for the first time, a challenge to HHS' adoption of a retroactive legislative rule. In Bowen v. Georgetown University Hospital, ${ }^{5}$ the Court invalidated a Medicare cost-limit reimbursement standard. The standard had been adopted in 1984 to replace a prior rule that had been invalidated for various procedural flaws. Pursuant to the new rule, the HHS had attempted to recoup reimbursement funds that health care providers had received in prior years. ${ }^{6}$

The Bowen opinions are significant in a variety of ways. First, Bowen shifted the focus of the Court's inquiry. The Court previously had heard cases regarding retroactivity in the context of legislation and agency statements having the effect of law, but the Court generally focused on interpreting the rule at issue rather than on the statutory authority of the adopting body. ${ }^{7}$ Justice Kennedy, diverging from this pattern, articulated a new "clear statement" principle of statutory construction and held that the power to adopt legislative rules with formal retroactive effect must "as a general matter ... be . . . conveyed by Congress in express terms." 8 The Bowen principle thus joins an increasingly large number of "clear statement" principles allegedly followed by the Supreme Court.9 Second, while the Kennedy opinion eschewed a discussion of the relevance of the Administrative Procedure Act (APA), Justice Scalia's concurring opinion did not. Althougl Justice Scalia appeared to accept a "clear statement" approach as appropriate, he attempted to demonstrate the independent relevance of the APA to the validity of the HHS rule at issue. ${ }^{10}$ During this discussion, Justice Scalia indicated his impression-apparently formed in large part on the basis of the number of citations in the Government's brief-that retroactive legislative rulemaking was infrequent. He observed that it is "evidently not a device indispensable to efficient government." 11

5. 488 U.S. 204, 213-15 (1988).

6. Id.

7. See infra text accompanying notes 52-109.

8. Bowen, 488 U.S. at 208.

9. See, e.g., Skinner v. Mid-America Pipeline Co., 490 U.S. 212, 224 (1989) ("Congress must indicate clearly its intention to delegate taxing power to the Executive"); see also Note, Intent, Clear Statements, and the Common Law: Statutory Interpretation in the Supreme Court, 95 Harv. L. REv. 892, 900 (1982) ("clear-statement model of statutory interpretation redefines the judicial role by deferring to the relative competence of congressional judgment and to the legitimacy of legislative authority"). In 1989, the Court propounded a particularly demanding clear statement principle applicable to congressional waiver of eleventh amendment immunity. See Dellmuth v. Muth, 491 U.S. 223, 230 (1989) ("evidence of congressional intent must be both unequivocal and textual").

10. Bowen, 488 U.S. at 216-20 (Scalia, J., concurring).

11. Id. at 224. 
The result in Bowen inay be entirely defensible given the available evidence that Congress intended to deny HHS the power to adopt retroactive cost-limit rules. ${ }^{12}$ However, it is inuch more difficult to understand and accept the general apphication of the new "clear statement" test. The "clear statement" approach to agency statutory authority may unduly restrict agency pohcymaking and, in the process serve, along with other recent developments, ${ }^{13}$ as one more incentive for agencies to inake policy by adjudication rather than by administrative rule.

The opmions in Bowen were written against a welter of conflicting Supreme Court opinions that focused on the retroactivity of statutes and agency regulations. Prior to Bowen, the Court had not clearly spoken on whether there is a presumption for or against retroactivity. Without acknowledging the confusion or seeking to explain it, Bowen seized on the cases that apphed a clear statement analysis-an analysis that disfavored retroactivity-and applied this principle in a new context. ${ }^{14}$ More could and slould be expected of the Supreme Court, especially since some of the justices recently have shown increased interest in the probleins of legal interpretation. ${ }^{15}$

This Article approaches the issues and problems raised by Bowen by briefly revisiting in Part I some of those cases that purport to deal with the choice of adjudication over rulennaking as a mode of adininistrative policyinaking. ${ }^{16}$ Althougl the precise contours of the active, confusing debate in the area are umimportant for current purposes, it is helpful

12. See infra text accompanying note 146.

13. See, e.g., Scalia, Back to Basics: Making Law Without Making Rules, Regulation, JulyAug. 1981, at 25 (noting increased oversight by the Office of Management and Budget).

14. This ipse dixit approach is time-worn, as Karl Llewellyn conclusively demonstrated over forty years ago. Llewellyn, Remarks on the Theory of Appellate Decision and the Rules or Canons About How Statutes are to be Construed, 3 VAND. L. REv. 395 (1950). On retroactivity itself, Llewellyn counterposes a prospectivity-favoring canon ("A statute imposing a new penalty or forfeiture, or a new liability or disability, or creating a new right of action will not be construed as having a retroactive effect.") to a retroactivity-favoring canon ("Remedial statutes are to be liberally construed and if a retroactive interpretation will promote the ends of justice, they should receive such construction."). Id. at 402.

15. See, e.g., Public Citizen v. Department of Justice, 491 U.S. 440, 467-82 (1989) (Kennedy, J., concurring) (holding that the plain meaning of "utilize" in the Advisory Committee Act, 5 U.S.C. App. $\S \S 1-15$ (1988), ought to be a sufficient basis for interpreting the statute, rather than extending the interpretation to include a study of legislative history); Kosak v. United States, 465 U.S. 848, 862-63 (1983) (Stevens, J., dissenting) (arguing that particular weight should be given to the specific language chosen by Congress-where Congress uses different language in similar provisions, it intends to relate a different interpretation); INS v. Cardoza-Fonseca, 480 U.S. 421, 453 (1987) (Scalia, J., concurring) (holding that a "clearly expressed legislative intent" was a sufficient basis for interpretation and that the plurality's examination of the legislative history was excessive and unnecessary). See generally Breger, Introductory Remarks, 1987 DUKE L.J. 362 (tracing the evolution of judicial views on statutory interpretation).

16. See infra text accompanying notes $25-38$. 
to examine Bowen's relationship to this debate because the result in Bowen may affect agencies' exercise of discretion in choosing a mode of policy development. Moreover, certain general assumptions underlying the adjudication versus rulemaking debate and the tests for permissible retroactivity applied in those cases have broad ramifications.

In Parts II, ${ }^{17}$ III, ${ }^{18}$ and IV, ${ }^{19}$ the Article examines Supreme Court and lower court opinions on retroactivity of statutes and regulations, as well as recent lower court opinions that apply the new Bowen clear statement rule. Finally, in Part $V, 20$ the Article focuses on the results of a survey of administrative agencies. The survey indicates the extent and the use of retroactive legislative rules, the reactions to Bowen, and various recommendations for future congressional, judicial, and administrative responses to the matter of retroactive legislative rules. ${ }^{21}$

At the outset it should be noted that the formulation of a definition of retroactivity is no easy task, as the literature demonstrates. ${ }^{22}$ Take these relatively simple cases:

1. The Environmental Protection Agency (EPA) for the first time adopts a standard for the release of sulfur dioxide from existing power plants. The regulation imposes civil penalties for pre-adoption releases of that pollutant in violation of the new standard.

2. The EPA promulgates a new sulfur dioxide standard with a compliance date two years in the future. Most or all plants within the scope of the regulation will need to dismantle pollution-control technology installed in response to a prior, less stringent EPA regulation and invest in new stack gas cleaning equipment.

3. A newly constructed power plant applies to the EPA for a permit to operate. The permit would have been granted under EPA regula-

17. See infra text accompanying notes 39-164.

18. See infra text accompanying notes $165-221$.

19. See infra text accompanying notes $222-260$.

20. See infra text accompanying notes 261-331.

21. Under the aegis of the Rulemaking Committee of the ABA's Administrative Law \& Regulatory Practice Section (of which Ernest Gellhorn was chair), a questionnaire was sent in the spring of 1989 to over 50 federal agencies inquiring about their use of retroactive legislative rules since 1980. More than three quarters of the agencies responded. With only a few notable exceptions, the respondents included the major executive departments and independent regulatory agencies.

22. See, e.g., DeMars, Retrospectivity and Retroactivity of Civil Legislation Reconsidered, 10 OHIO N.U.L. REV. 253, 255-57 (1983) (discussing the confusion between retroactivity, which voids, modifies, or affirms pre-existing legal rules, and retrospectivity, which "attaches new future legal consequences to an event that occurred before the statute was passed"); Slawson, Constitutional and Legislative Considerations in Retroactive Lawmaking, 48 CALIF. L. REV. 216, 216 (1960) (retroactive law may be "used both (1) to describe a particular basis of selection for the direct imposition of legal effects and (2) as a description of particular kinds of effects which may occur when a new law is imposed"). For a recent example of a court struggling to determine whether a particular agency statement was "retroactive," see Chemical Waste Management, Inc. v. EPA, 869 F.2d 1526, 1534-37 (D.C. Cir. 1989) (court examined notice and comment requirements, similar statutes, prior case law and the merits of retroactive application to conclude retroactivity was valid). 
tions in effect during the construction phase of the facility, but it is denied based on new EPA regulations adopted between the time of application and final agency action on the permit.

Under one common definition, a retroactive regulation gives preadoption conduct a different legal effect from the one it would have had without the adoption of the regulation. ${ }^{23}$ Under this view, only the first case posed above is clearly a case of formal retroactivity. The third case is somewhat problematic in that regard, and the second case would fall outside this account of retroactivity. ${ }^{24}$ Yet all of these cases and variations provoke concern for the same reasons: They create "surprise" and a potential for undermining "reasonable" reliance by affected parties. When a certain activity occurred, apparently applicable legal principles either signaled approval or at least did not suggest disapproval. Retroactivity may threaten these expectations with "disappointment" and unforeseen costs. The destabilizing effects of retroactive regulation suggest the need to come to terms with the permissible parameters of retroactivity.

The impact of Bowen in the area of administrative law and beyond depends, to a great degree, on the Court's concept of retroactivity, the contours of which are still obscure. Whatever the scope and meaning of the Court's interpretive principle, however, Bowen's practical inpact on agency discretion and pohicymaking may indeed be great as agencies choose to avoid the risk of invalidation of their actions by refusing to act or by opting for the adjudicatory process for policymaking.

As a starting point for analyzing Bowen, the focus of attention will be the Supreme Court opimions outlining this core of agency discretion to choose between the adjudicatory and policymaking node.

\section{The CHENERY IsSUe Revisited}

\section{A. Discretion to Choose the Policymaking Mode}

Agencies authorized both to adopt legislative rules and to adjudicate violations of general statutory standards liave to clioose whetlier to elaborate substantive policy in the forn of a legislative rule-a pronouncement whicli looks hike and lias the effect of a statute adopted by Congress-or on a case-by-case basis as part of the decision of individual

23. See Hochman, The Supreme Court and the Constitutionality of Retroactive Legislation, 73 HARV. L. REV. 692, 692 (1960).

24. See also McNulty, Corporations and the Intertemporal Conflict of Laws, 55 CALIF. L. REv. $12,58-60$ (1967). McNulty distinguishes "primary" retroactivity, which reaches back to alter legal consequences of events from the time of those events, from "secondary" retroactivity, which affects only future legal consequences from the date of adoption of the new law. The second case described above would be classified as an instance of secondary retroactivity under this scheme. 
controversies. Soon after the enactment of the Administrative Procedure Act in 1946, ${ }^{25}$ the Supreme Court first examined the general issue of agency discretion to choose between rulemaking and adjudication in $S E C$ v. Chenery Corp (Chenery In). ${ }^{26}$ In a frequently quoted (although hotly disputed) passage, Justice Murphy observed,

Since the [Securities and Exchange] Commission, unlike a court, does have the ability to make new law prospectively through the exercise of its rulemaking powers, it has less reason to rely upon ad hoc adjudication to formulate new standards of conduct within the framework of the Holding Company Act. The function of filling in the interstices of the Act should be performed, as much as possible, through this quasilegislative promulgation of rules to be applied in the future. ${ }^{27}$

Justice Murphy's view makes an implicit analogy between administrative rules and statutes and assumes that legislative rules generally will be prospective in effect. But since Chenery II involved a retroactive adjudicatory pronouncement, not a legislative rule, this case can hardly be taken to stand for the proposition that legislative rules should or inust be exclusively prospective. Rather, the point of Justice Murphy's statement was that legislative rules are one way to avoid problems (such as surprise) created by an agency's failure to clearly articulate policy prior to individual adjudication.

The Chenery II Court permitted retroactive policy developed through adjudications. The Court noted that, in a variety of circumstances, before-the-fact policymaking was neither feasible nor desirable. Thus, the Court reasoned, the announcement and application of new or changed policy through agency adjudication was legitimate. ${ }^{28}$ Expressly mentioning three such instances, ${ }^{29}$ the Court opined that "the choice made between proceeding by general rule or by individual, ad hoc litigation is one that lies prinarily in the informed discretion of the administrative agency." 30 Where retroactive effects result from courts and agencies announcing and applying new principles, the Court said,

[S] uch retroactivity must be balanced against the mischief of producing a result which is contrary to a statutory design or to legal and equitable principles. If that mischief is greater than the ill effect of the

25. Administrative Procedure Act, 5 U.S.C. $\$ 571$ (1988).

26. 332 U.S. 194 (1947). It should be noted that the Chenery II proceedings began long before the enactment of the APA, and were in no way governed by the APA.

27. Id. at 202 (emphasis added).

28. Id. at 202-03.

29. The three instances mentioned by the Court in which an agency might resort to adjudicative policymaking were unforeseeable problems, lack of experience with the problem, and inability to formulate a rule of sufficient specificity. $I d$.

30. Id. at 203. 
retroactive application of a new standard, it is not the type of retroactivity which is condemned by law. ${ }^{31}$

The analogy between agency adjudication and judicial proceedings is apparent, as is the view that adjudication generally operates retroactively and rulemaking generally functions prospectively. Since Chenery $I I$ involved the application of a seemingly retroactive adjudicative pronouncement, the main line of the administrative law debate that surrounds the case has focused on situations in which an adjudicatory proceeding serves as the vehicle for either prospective or retroactive agency policymaking. ${ }^{32}$ With the enactment of the APA, that debate focused mamly on the appropriateness of particular procedures for administrative pohicymaking. The issue became the applicability of noticeand-comment procedures in instances in which an agency purported to make policy. ${ }^{33}$

\section{B. A Proposed Test for Permissible Retroactivity}

Retroactive adjudicative pronouncement is not the only form of agency action that may have retroactive legal consequences. Regulated entities may be affected by four superficially different agency actions: the creation and application of a new "common law" policy in an adjudication (retroactive adjudicative pronouncement); the attribution of a "new" meaning to an existing regulation; the interpretation of a new regulation to apply to pre-adoption occurrences where the regulation does not, on its face, suggest its retroactive apphication; and the express inclusion of retroactive language in a substantive rule. ${ }^{34}$ One of the most important lower court cases that followed from Chenery II was Retail, Wholesale, and Department Store Union v. $N L R B,{ }^{35}$ which attempted to clarify the

31. Id.

32. See, e.g., NLRB v. Bell Aerospace Co., 416 U.S. 267, 294 (1974) (National Labor Relations Board (NLRB) not precluded from establishing new principles in an administrative proceeding, and it is within the NLRB's discretion to choose between rulemaking and adjudication); see also Bonfield, Mandating State Agency Lawmaking by Rule, 2 B.Y.U. J. PuB. L. 161, 217 (1988) (suggesting that state agencies authorized to make rules only resort to lawmaking by adjudication when rulemaking would be unrealistic under the circumstances); Robinson, The Making of Administrative Policy: Another Look at Rulemaking and Adjudication and Administrative Procedure Reform, 118 U. PA. L. REV. 485 (1970) (arguing that the APA acts as a hinderance to adapting administrative procedures to the particular needs of given agencies).

33. See, e.g., NLRB v. Wyman-Gordon Co., 394 U.S. 759, 766 (1969) (criticizing NLRB's avoidance of notice-and-comment procedures in issuing an order directing an election to be held); see also Mayton, The Legislative Resolution of the Rulemaking Versus Adjudication Problem in Agency Lawmaking, 1980 DUKE L.J. 103, 103-04 (proposing that the courts have not effectively enforced the rulemaking requirement and have given agencies discretion to develop rules by adjudication).

34. Cf. Weaver, Retroactive Regulatory Interpretations: An Analysis of Judicial Responses, 61 Notre DAME L. REV. 167 (1986).

35. 466 F.2d 380 (D.C. Cir. 1972). 
Chenery II test for permissible retroactivity. Despite the fact that both Chenery II and Retail, Wholesale involved only the first of the situations posed above-application of a new "common law" rule-the test formulated in Retail, Wholesale has been applied in all four contexts. ${ }^{36}$ The D.C. Circuit in Retail, Wholesale noted,

Among the considerations that enter into a resolution of the problem [of retroactivity] are (1) whether the particular case is one of first impression, (2) whether the new rule represents an abrupt departure from well established practice or merely attempts to fill a void in an unsettled area of law, (3) the extent to which the party against whom the new rule is applied relied on the former rule, (4) the degree of the burden which a retroactive order imposes on a party, and (5) the statutory interest in applying a new rule despite the reliance of a party on the old standard. ${ }^{37}$

This equitable formula focuses attention on the degree of "surprise," the harm to the party burdened by the new policy, and the need, in terms of fulfilling the statutory goal, for retroactive effect. The test permits a flexibility that invites close case-by-case inquiry instead of broad generalization. Accordingly, where, for example, the burden imposed by a new rule on a party is minimal, the required showing in terms of statutory need would be similarly reduced. ${ }^{38}$

In sum, Chenery II and Retail, Wholesale established that agencies may implement "new" policies retroactively in the context of an adjudication. This leaves open the question of whether new policies which are expressly made retroactive can be promulgated by an agency using the rulemaking procedures provided in the APA. At least formally, this question presents a different case than retroactivity in the adjudicatory context, because it directly implicates the scope of the statutory grant of rulemaking power to the agency. This in turn raises issues of constitutional law and statutory interpretation; constitutional limits on Congress' ability to act retroactively also apply to its delegates-administrative agencies. Interpretive approaches for determining the temporal scope of legislation and regulations inay be of relevance in approaching the associated, though not identical, issue of interpreting the scope of statutory grants of rulemaking power to agencies.

36. See Weaver, supra note 34 , at 175 ; see also infra text accompanying notes 110-35.

37. Retail, Wholesale, 466 F.2d at 390.

38. In Retail, Wholesale, Judge McGowan noted that "[u]nless the burden of imposing the new standard is de minimis, or the newly discovered statutory design compels its retroactive application, the principles which underlie the very notion of an ordered society, in which authoritatively established rules of conduct may fairly be relied upon, must preclude its retroactive effect ..." Id. at 392. This language suggests some presumption against permissible retroactive application. 


\section{Judicial Rulings on REtroactive Rules}

\section{A. Retroactivity of Statutes: Constitutional Limitations}

Constitutional restrictions on retroactivity are linked to the prohibitions against both ex post facto laws ${ }^{39}$ and takings without just coinpensation, ${ }^{40}$ the contracts clause, ${ }^{41}$ and the due process clause. ${ }^{42}$ Since the administrative regulations at issue generally are not presented in a criminal context, the first limitation is largely beside the point, ${ }^{43}$ and because federal regulation is the focus of attention, the impairment of contracts prohibition falls by the wayside because it only applies to action by the states. ${ }^{44}$ "Takings" jurisprudence may not impose restraints more demanding than due process. ${ }^{45}$ In fact, much of the judicial and scholarly analysis of retroactivity in the statutory context focuses on due process problems. ${ }^{46}$ The due process analysis inay inpose constraints on retroactive agency rules.

Professor Hochman suggests that Supreine Court decisions indicate that agency conformity with the dictates of due process depends on a case-by-case balancing of three factors: (1) the nature and strength of the public interest served by the statute; (2) the extent to which the statute inodifies or abrogates the asserted preenactinent right; and (3) the nature of the right that the statute alters. ${ }^{47}$ Not surprisingly, this test bears a close familial resemblance to those in Chenery II and Retail, Wholesale. ${ }^{48}$ With regard to their substantive validity, recent Supreme Court cases involving retroactive federal statutes have applied a garden-

39. U.S. CoNST. art. I, $\S \S 9-10$.

40. Id. amend. $\mathrm{V}$.

41. Id. art. I, $\S 10$.

42. Id. amend. V; see also id. amend. XIV, §1.

43. See Calder v. Bull, 3 U.S. (3 Dall.) 386 (1798) (constitutional prohibition against ex post facto laws not to be applied strictly and absolutely).

44. See id. at 389.

45. Under the current regulatory takings jurisprudence, the Court is unlikely to label a regulation a taking if the regulation advances some public interest and does not destroy any of what are recognized as the bundle of rights subsumed under the label "property." See Penn Central Transp. Co. v. New York City, 438 U.S. 104 (1978). Even if a particular agency action were found to be a taking, this would have little direct effect on all retroactive statutes, because the Court has applied takings analysis on a case-by-case basis. See Keystone Bituminous Coal Ass'n v. DeBenedictis, 480 U.S. 470, 475 (1987). But see United States v. Security Industrial Bank, 459 U.S. 70 (1982). See also Eule, Temporal Limits on the Legislative Mandate: Entrenchment and Retroactivity, 1987 AM. B. Found. Res. J. 379, 430-32. See generally Fox, Federal Constitutional Limitations on the Regula. tion of Coal Mining Activities, 3 J. MiN. L. \& PoL'y 1 (1987).

46. See, e.g., Hochman, supra note 23, at 694-97; see also League v. Texas, 184 U.S. 156 (1902).

47. See Hochman, supra note 23, at 697, 726-27.

48. See supra text accompanying notes 31 and 37 . 
variety rationality standard with a presumption in favor of the legislative judgment, but without a presumption against retroactivity. ${ }^{49}$

\section{B. Retroactivity and the Interpretation and Application of Statutes and Administrative Regulations}

Between 1964 and 1985, the Supreme Court expressed neither unremitting hostility toward nor unwavering endorsement of retroactivity in cases that dealt with the interpretation and application of statutes and administrative regulations. In some instances the Court attempted, although not convincingly, to reconcile varying approaches to retroactivity. ${ }^{50}$ In other cases, the Court apparently accepted the existence of two inconsistent canons of imterpretation without providing meaningful guidance for choosing between them. ${ }^{51}$

1. Inconsistent Canons Side-by-Side: Greene v. United States and Thorpe v. Housing Authority. In its 1959 decision in Greene v. McElroy, the Court set aside the Governinent's revocation of a security clearance. $^{52}$ Following the suit, the successful petitioner asked the Department of Defense (DOD) to provide inonetary restitution for his lost earnimgs; he based his claim on a 1955 DOD regulation that granted equitable reimbursement to a contractor's employee who successfully litigated a claim relating to a suspension of a clearance. But the DOD would only consider the clain under a more restrictive 1960 regulation issued after the clain had arisen and been fornally presented. In Greene v. United States, on appeal from the Court of Claims, the Supreme Court held that, because the petitioner's rights "matured" under the 1955 rule, his claim must be evaluated under that provision. ${ }^{53}$ The Court invoked "the first rule of construction" for agency regulations and statutes, holding that "retrospective operation will not be given to a statute which interferes with antecedent rights ... unless such be 'the unequivocal and

49. See, e.g., Pension Benefit Guar. Corp. v. R.A. Gray \& Co., 467 U.S. 717, 729 (1984) ("strong deference accorded legislation in the field of national economic policy is no less applicable when that legislation is applied retroactively"); see also Usery v. Turner Elkhorn Mining Co., 428 U.S. 1, 16-18 (1976) (suggesting that under the due process clause the justification for prospective legislation may differ from that used in the case of retroactive legislation because of reliance interests present in the latter and not the former, but that the ultimate standard-reasonableness-is the same in both cases); Eule, supra note 45 , at 429 (the party asserting a violation of due process often cannot overcome the burden of proving irrationality).

50. See, e.g., Bennett v. New Jersey, 470 U.S. 632 (1985); Greene v. United States, 376 U.S. 149 (1964).

51. See, e.g., Bradley v. School Bd., 416 U.S. 696 (1974); Thorpe v. Housing Auth., 393 U.S. 268 (1969).

52. 360 U.S. $474,502-04$ (1959).

53. 376 U.S. 149,160 (1964). 
inflexible import of the terms, and the manifest intention of the legislature." "54 The Court applied the 1960 DOD rule prospectively55-despite the construction by the agency that adopted the regulation. Thus, the Court departed from its usual practice of giving deference to an agency's interpretation of its own regulations. In effect, the Court seemed to apply a presumption against retroactive application of administrative regulations.

Five years after Greene applied a presumption against retroactivity, the Court-ruling on the retroactivity of a Housing and Urban Development (HUD) eviction regulation in Thorpe v. Housing Authority ${ }^{56}-$ discovered and apphied a different canon of interpretation. The plaintiff-a montl-to-montl tenant in a federally-assisted, low-rent housing project-contended that slie was improperly evicted on the basis of her organizational activities. The plaintiff argued that the housing authority's failure to loold an administrative liearing or issue a statement of reasons for the eviction violated the due process clause of the fourteenth annendment. ${ }^{57}$ While the case was pending in the Supreme Court, HUD issued a rule that required operators of local federally-assisted projects to inform tenants of the reasons for eviction and give them an opportunity to make a reply before instituting eviction proceedings.

The Court avoided the due process claim and found the new HUD rule retroactively applicable, despite the lack of any express agency intention on the retroactivity issue. ${ }^{58}$ The Court invoked the "general rule" that "an appellate court must apply the law in effect at the time it renders its decision [unless there would be] manifest injustice." 59 Because the HUD rule was an administrative regulation with the force of law, the Court treated it like a statute. ${ }^{60}$ Altliough the rule in Thorpe was "procedural," in a general sense, the Court did not limit the ainbit of the constructional canon to procedural matters.

The Thorpe Court atteinpted to reconcile its decision with the Greene canon. According to Chief Justice Warren, who wrote the opinion in Thorpe, the petitioner's riglits to reimbursenent in Greene had "vested" as a result of the Court's earlier decision in McElroy. ${ }^{61}$ Accordingly, there would have been "Inanifest injustice" if the later-adopted

54. Id. (quoting Union Pac. R.R. Co. v. Laramie Stock Yards Co., 231 U.S. 190, 199 (1913)).

55. $I d$.

56. 393 U.S. 268 (1969).

57. Id. at 272.

58. Id. at 281-83.

59. $I d$. at 281-82.

60. Id. at 282 .

61. See id. 
regulation had been applied in Greene. ${ }^{62}$ However, Greene neither makes reference to "manifest injustice" nor to the canon which includes the manifest injustice exception. In short, Thorpe reads into Greene a test that was not apphed in the earher case. Greene applied a presumption against giving retroactive effect to agency rules. Thorpe did just the opposite, applying a presuniption that favors retroactivity.

2. Further Application and Attempted Reconciliation of the Two Canons: Bradley v. Scliool Board and Bennett v. New Jersey. Five years later in Bradley v. School Board, the Court once again suggested that retroactivity was favored, except when retroactive application would result in manifest injustice. ${ }^{63}$ In 1971, the district court in Bradley awarded attorneys' fees to plaintiffs-in the absence of explicit statutory authorization for such action-in a protracted scliool desegregation litigation. ${ }^{64}$ The court justified the recovery on the basis of the school board's "obstinate unreasonable" delay in the desegregation of the schools ${ }^{65}$ and the role of the plaintiffs as "private attorneys general" in forcing the defendant to coinply with the law. ${ }^{66}$ After the initial submission of this case to the court of appeals, but prior to its decision, the Education Amendments of $1972^{67}$ took effect, granting express authority to federal courts to award reasonable attorneys' fees in school desegregation cases. ${ }^{68}$ After the Fourth Circuit reversed the district court, the Supreme Court granted the petition for certiorari. According to the Court, the issue was whether the statute autlorized an award of fees when those expenses were incurred prior to the effective date of the statute. 69

Answering this question in the affirmative, the Court invoked "the principle that a court is to apply the law in effect at the time it renders its decision, unless doing so would result in manifest injustice or there is statutory direction or legislative listory to the contrary."70 This "rule" originated in Chief Justice Marshall's opinion in United States v. The

62. Id.

63. 416 U.S. $696,715-16$ (1974).

64. 53 F.R.D. 28 (E.D. Va. 1971), rev'd, 472 F.2d 318 (4th Cir. 1972), vacated, 416 U.S. 696 (1974).

65. Id. at 39 .

66. Id. at 42.

67. Pub. L. No. 92-318, 86 Stat. 235, 369 (1972).

68. Emergency School Aid Act, $\$ 718,86$ Stat. 369 (1972) (codified as amended at 20 U.S.C. $\S 1617$ (1970 ed. Supp. II)), repealed by Pub. L. No. 95-591, 92 Stat. 2268 (1978).

69. Bradley v. School Bd., 416 U.S. 696, 710 (1974).

70. Id. at 711. 
Schooner Peggy. ${ }^{71}$ According to the Bradley Court, Thorpe laid to rest some uncertainty with regard to the scope of the rule of The Schooner $P$ Pggy 72 and firmly established that "even where the intervening law does not exphicitly recite that it is to be applied to pending cases, it is to be given recognition and effect." 73 The Bradley Court did not suggest limiting this approach to instances, such as Thorpe, in which avoidance of serious constitutional issues may have motivated the choice of the interpretative canon. In addition, the Bradley Court-following the lead of Thorpe-interpreted Greene to involve "manifest injustice."74

The Bradley Court explained that the "manifest injustice" standard served to limit retroactive effect and thus mitigate substantial hardship which might flow from retroactive application. Three factors were relevant in assessing "manifest injustice": (1) the nature and identity of the parties; (2) the nature of their rights; and (3) the nature of the inipact of the change in law upon those rights. ${ }^{75}$ The similarity to the Chenery II, Retail, Wholesale, and due process tests for permissible retroactivity is striking. ${ }^{76}$

Finally, Bennett v. New Jersey 77 added a further layer of complexity to the Court's approach to retroactivity. Although the Court declined to apply a presumption of retroactivity in a situation in which substantive or vested rights were allegedly at issue, it did adnit the existence of two apparently inconsistent interpretive canons. Title I of the Elenientary and Secondary Education Act of $1965^{78}$ provided federal grants-in-aid to support compensatory education for disadvantaged children in low-income areas. After determining that applications of local education agencies complied with federal requirements, states were to distribute Title I funds to school districts. The federal government supplied funds based on assurances by the states that the money would be spent only on programs meeting the requirements of the statute. In Bennett, the Office (now Department) of Education demanded in 1976 that New Jersey repay $\$ 1,031,304$ in Title I funds that were allegedly spent inproperly during the years 1970-72. Following exhaustion of its administrative

71. 5 U.S. (1 Cranch) 103, 110 (1801). In The Schooner Peggy, the Court held that, other than in "private cases between individuals," a court must "in great national concerns .... decide according to existing laws, and if it be necessary to set aside a judgment, rightful when rendered, but which cannot be affirmed but in violation of law, the judgment must be set aside." Id.

72. Bradley, 416 U.S. at 712-14.

73. Id. at 715 .

74. Id. at $716-17 \&$ n. 24 .

75. Id. at 717.

76. See supra text accompanying notes 31 and 37 .

77. 470 U.S. 632 (1985).

78. Pub. L. 89-10, 79 Stat. 27 (1965) (codified as amended in seattered sections of 20 U.S.C.). 
remedies, the state appealed to the Court of Appeals for the Third Circuit, which held that the Department had no authority to issue the order demanding repayment. ${ }^{79}$ The Supreme Court disagreed and remanded. ${ }^{80}$ On remand, the state introduced the arguinent that the 1978 amendments to Title $\mathrm{I}^{81}$ should be the substantive standard by which to determine whether the disputed expenditures of 1970-72 had been misused. ${ }^{82}$ Relying on Bradley, the Third Circuit held that the amendments should operate retroactively. On certiorari, the Supreme Court again reversed, holding that reliance on Thorpe's presumption of retroactivity was inappropriate in this context, and that the state's expenditures must be evaluated according to the law in effect when the grants were made. ${ }^{83}$

The Bennett Court distinguished Bradley by suggesting that "matured" or vested rights were at issue in Bennett, and thus, the inanifest injustice exception was applicable. ${ }^{84}$ Moreover, a refusal to find retroactivity "comport[ed] with another venerable rule of statutory interpretation, i.e., that statutes affecting substantive rights and liabilities are presumed to have only prospective effect." 85 The Court cited Greene to support this conclusion. ${ }^{86}$ Thus, the Court allowed the continued existence of two coinpeting constructional canons without describing the scope of their respective applications.

3. Reconciling Greene and Thorpe. In suin, over a space of eleven years the Court decided four cases involving the interpretation of statutes and administrative rules whose retroactive application was at issue. First, in Greene the Court applied what appeared to be a general presumption against retroactivity, only to adopt the opposite presuinption in Thorpe and Bradley. Those decisions "explained Greene" as an exception to the norm. Finally, im Bennett, the Court rejected retroactive application of the statute at issue, finding the Greene exception on point and also noting the existence of a general canon of interpretation disfavoring retroactivity.

79. New Jersey Dep't of Educ. v. Hufstedler, 662 F.2d 208, 209-10 (3d Cir. 1981), rev'd sub nom. Bell v. New Jersey, 461 U.S. 773 (1983).

80. Bell v. New Jersey, 461 U.S. 773, 793 (1983).

81. Pub. L. 95-561, 92 Stat. 2143 (1978) (codified as amended in scattered sections of 20 U.S.C.).

82. New Jersey Dept. of Educ. v. Hufstedler, 724 F.2d 34, 37 (3d Cir. 1983), rev'd sub nom. Bennett v. New Jersey, 470 U.S. 632 (1985).

83. Bennett v. New Jersey, 470 U.S. 632,638 (1985).

84. Id. at $638-39$.

85. Id. at 639 .

86. Id. at 640 . The Court, however, used a "cf." cite to Bradley in order to indicate that the holding in Bradley was premised on the notion that no "substantive obligations" were there affected. 
The Bennett Court's reliance on vested rights was an attempt to find a meaningful distinction between Greene and Thorpe. However, the Court was not clear about the scope or basis of the distinction between vested rights and nonvested rights. Commentators have long agreed that an analysis of retroactive effect based on the "vestedness" of the right in question is unpersuasive. ${ }^{87}$

Rehiance on the substance/procedure distinction to determine when a rule will be applied retroactively proves equally problematic. Thorpe and Bradley might be viewed as involving matters of "procedure," as opposed to the "substantive riglits" at risk in Greene and Bennett. However, the Court's attempt to fit Greene into the Thorpe rule ${ }^{88}$ - that a presumption of retroactivity prevails unless sucli an application would result in manifest injustice-appears to eliminate the substance/procedure dicliotomy as a basis for reconciliation.

Similarly, Thorpe's attempted "incorporation" of Greene makes it difficult to limit the scope of the Thorpe retroactivity canon in a temporal fashion to cases in which the new rule takes effect during the litigation where it might apply. In Greene, the change in law-applied only prospectively-predated the litigation. However, the change was subsequent to the administrative filing of the claim. In Bennett, the statutory change occurred early in the federal adinmistrative proceedings on the federal demand for repayment, but before the case was first heard by the Third Circuit in 1980. If the timing of the change determines the interpretive canon to be invoked, then the Bennett-type case is not easily pigeonloled. This is particularly true given the Court's failure to articulate any policies that might suggest limiting Thorpe to changes in law during litigation.

In determining whether Thorpe can be limited based on the timing of the new rule's adoption relative to the posture of the case, ${ }^{89}$ it is im-

87. See, e.g., Hochman, supra note 23 , at 696 .

88. See supra text accompanying notes 56-62.

89. Other attempted formal distinctions designed to limit Thorpe are, ultimately, unconvincing. For example, the approach in Thorpe does not expressly purport to rest on an "interpretation" of the statute or regulation in question but rather on the court's "obligation" to apply "existing law." See Thorpe v. Housing Auth., 393 U.S. 268, 282 (1968) (citing United States v. The Schooner Peggy, 5 U.S. (1 Cranch) 103, 110 (1801)). However, clearly it is not the "obligation" of a court to apply a particular rule if the legislature or agency has not intended the law to apply to pending cases. Thus, in order to fulfill its obligations, the court must ascertain the intended scope of the new rule, the heart of the interpretative function.

It might also be argued that Thorpe involved a situation in which the Court applied a regulation to a particular case and did not necessarily indicate that all "similar" instances (even those not litigated) should be governed by the new rule at issue. Yet Bennett resolved the statutory issue presented (the legal standard for determining repayment obligations) in language that suggested application beyond the scope of the litigation presented. See Bennett v. New Jersey, 470 U.S. 632, 
portant to note that, under slightly different circumstances, the proposed temporal distinction would result in the opposite result from the one reached by the Court in Greene. If the DOD in Greene had denied the claim for back wages on the basis of the old regulation and subsequently promulgated the new, more restrictive rule during the course of litigation challenging this denial, the Supreme Court-applying a temporal distinction-would have applied the presumption in favor of retroactivity to the new regulation!

It is of inore than passing interest to contemplate why the Court would on occasion feel the need to adopt a presumption against applying a statute retroactively. ${ }^{90}$ The invocation of clear statement principles is a traditional way to avoid difficult or close constitutional issues. ${ }^{91}$ But if the constitutional validity of retroactive application is a foregone conclusion as it was, for exainple, in Bennett (where the state itself argued in favor of retroactivity), then this explanation for a presumption against retroactivity fails. ${ }^{92}$ Perhaps where congressional intent is either obscure or non-existent, relymg on a presumption produces a starting point for analysis and, since inost legislation is prospective in operation, a presuinption against retroactivity makes some intuitive sense. However, this argument fails to explain why in Thorpe and its progeny the Court adopted the opposite presumption.

There is, however, a possible way to explain the invocation of seemingly opposing canons. The Court invokes the Greene canon (against retroactive effect) as a shorthand method of "explaming" the result in situations in which an inplicit balancing analysis-similar to Retail, Wholesale - points toward non-retroactivity. In situations in which balancing points toward permissible retroactivity, the Court relies on the Thorpe canon as an "explanation" for finding retroactive effect. An acceptance of this explanation, however, does not eliminate the difficulty in

641 ("changes in the substantive standards governing federal grant programs do not alter obligations and liabilities arising under earlier grants").

It should be noted here that the Thorpe canon, which directs the application of law, in effect, implicitly indicates the distinction between the legal effectiveness of the rule of law and its retroactive reach. See infra note 220. The effective date of a rule of law is determined by the lawmaking body and, ideally, retroactive reach also should be determined expressly by the legislature or agency; but, in default of that, it must be determined by the tribunal with adjudicatory power, as a matter of "interpretation" or otherwise.

90. See Eule, supra note 45 , at $428-34$.

91. See, e.g., United States v. Security Indus. Bank, 459 U.S. 70, 78-80 (1982) ("retroactive operation will not be given to a statute which interferes with antecedent rights ... unless such be 'the unequivocal and inflexible import of the terms and the manifest intention of the legislature' ") (quoting Union Pacific R.R. Co. v. Laramie Stock Yards Co., 231 U.S. 190, 199 (1913)).

92. To the extent the constitutional test for permissible retroactivity is not a particularly demanding one, see supra text accompanying note 49 , the basis for the Greene canon is not self-evident. But see infra text accompanying notes 177-81. 
drawing clear guidance from the Court's caselaw as to the retroactive scope of statutory grants of rulemaking power.

\section{Supreme Court Case Law Regarding Agency Authority to Adopt Retroactive Rules}

The Court's opinion in Bowen v. Georgetown University Hospital focused on the authority of an agency to act retroactively. Although both Greene and Thorpe dealt with the application of administrative rules, the Court resolved these issues without bothering to explore the scope of the congressional delegation to the agencies whose rules were involved. However, both prior to and following Greene and Thorpe, the Court did on occasion address itself to the problem of an agency's legal authority to adopt retroactive administrative regulations. Although these cases suggest that retroactive administrative rulemaking niay require a persuasive showing of need, they do not deniand an express or "clear" statutory grant of authority.

1. Addison v. Holly Hill Fruit Products and Approval for Retroactive Rulemaking. Prior to Bowen, there were relatively few cases in which the Supreme Court directly confronted the question of agency authority to act retroactively through pronouncenients that have some or all of the characteristics of a statute. ${ }^{93}$ The principal example is Addison v. Holly Hill Fruit Products, ${ }^{94}$ a case that involved the validity of a regulatory exemption from the minimum wage and overtime requirenients of the Fair Labor Standards Act (FLSA). ${ }^{95}$ The Addison Court invalidated the rule because it was inconsistent with legislative intent and remanded the case to the district court to await new rulemaking by the Wage and Hour Administrator that would further define the scope of the exeniption. ${ }^{96}$ But faced with the alternatives of entirely depriving a class of employees of the FLSA's protection or allowing all such employees to be covered, the Court, despite congressional intent for partial coverage, permitted retroactive operation of the forthcoming rules. The Court noted that retroactivity in the law should be avoided, but reasoned that "other possible dispositions likewise involve retroactivity, with the added mis-

93. See, e.g., Transcontinental and Western Air v. Civil Aeronautics Bd., 336 U.S. 601 (1949) (involving retroactive mail rates to be paid by the U.S. Government; the Court construed the agency's ratemaking authority to permit only prospective changes based on the "customary pattern of fixing rates prospectively," legislative history, and the overall pattern of the statutory scheme at issue); United States v. Morgan, 307 U.S. 183 (1939) (ratemaking); Atlantic Coast Line R.R. Co. v. Florida, 295 U.S. 301 (1935) (ratemaking).

94. 322 U.S. 607 (1944).

95. 29 U.S.C. $\S \S 201-219$ (1988).

96. 322 U.S. at 619. 
chief of producing a result contrary to the statutory design."97 The Court did not identify an express statutory provision in the FLSA that authorized retroactive rulemaking, and instead based its disposition on judicial remedial power. ${ }^{98}$

Justice Rutledge filed a spirited dissent from both the decision on the merits and the acceptance of retroactive rulemaking in general. $\mathrm{He}$ suggested that "the decision opens the door to a general expansion of the novel, and I think unauthorized, practice of retroactive adininistrative determination of private rights." 99 He argned that some "clear congressional inandate" should be required for admimistrative retroactivity. 100

In short, the Addison inajority approved retroactive rulemaking in the absence of any apparent statutory basis. On the other hand, the dissent suggested a clear statement rule that disfavored retroactivity, an approach later adopted by the Court in Bowen. However, the Bowen Court did so without express reliance on Justice Rutledge's opinion.

2. The Border Between Rulemaking and Adjudication. Forty years after Addison, the Court handed down its decision in Interstate Commerce Commission v. American Trucking Associations, ${ }^{101}$ a case that bears on the issue of retroactive rulemaking authority. American Trucking involved regulation of inotor carrier rates by the Interstate Commerce Commission (ICC). At issue was whether the ICC could impose retroactive liabihity for violation of rate schedules.

Motor-carrier rate bureaus are groups of inotor carriers formed to negotiate collective rates, an activity that is exempted froin the antitrust lavs. Rate bureau agreements describing how the rates are negotiated are subject to ICC approval. In 1980, however, Congress acted to limit the agency's discretion to disapprove proposed rate agreements. In that year, the ICC issued an interpretative ruling that outlined its understanding of the new legislation and announced its intention to fashion a new remedy for violations of approved rate bureau agreements. The stated remedy was tariff rejection, which meant that carriers which operated under the rejected tariff would be liable to shippers for rates charged in excess of any tariff in effect prior to the rejected one.

The applicable statute expressly provided for a damages remedy when the ICC found a rate bureau-submitted tariff unlawful, but the legislation did not provide for tariff rejections to be applied retroactively.

97. Id. at 620 .

98. Id. at 622 .

99. Id. at 639.

100. Id. at 641 .

101. 467 U.S. 354 (1984). 
The American Trucking Court said that the issue presented was whether, "in addition to [its other] remedial powers ... the Commission has the authority to reject retroactively a tariff submitted in substantial violation of a rate-bureau agreement once that tariff has gone into effect." 102 The Court did not characterize tariff rejection as "rulemaking." Although the ICC's action could be characterized as adjudicatory, 103 the effect of rejection bears close resemblance to retroactive agency rulemaking. Tariff rejection would reestablish a prior tariff for purposes of liability actions brought by shippers against carriers who had observed the collective rate. It would also mean that those saine carriers had to comply with the reestablished tariff $\mathrm{m}$ the future until a new rate was filed.104

Examining the ICC's assertion of authority, the Court noted that "[t] he Commission's authority under the Interstate Commerce Act is not bounded by the powers expressly enuinerated in the Act."105 Rather, "the Commission also has discretion to take actions that are 'legitimate, reasonable, and direct[1y] adjunct to the Commission's explicit statutory power." "106 The Court found that "[t]o lie within the Coinmission's discretionary power, the proposed remedy must satisfy two criteria: first, the power must further a specific statutory inandate of the Coinmission, and second, the exercise of power must be closely tied to that mandate." 107 In explaining this "doctrine of discretion," the Court noted that "since drafters of complex ratemaking statutes ... neither can nor do 'include specific consideration of every evil sought to be corrected,' the absence of express remedial authority should not force the Commission 'to sit idly by and wink at practices that lead to violations' . . ."108 In American Trucking, the tariff rejection power inet the Court's standards.

The test articulated in American Trucking did not originally arise in response. to retroactivity problems. In fact, the American Trucking

102. Id. at 360 . In a prior case somewhat analogous to American Trucking, the Court held that the ICC lacked authority to award reparations against carriers who acted in compliance with a rate which the Commission had previously declared to be a rcasonable one. Id. See Arizona Grocery Co. v. Atchison, Topeka \& Santa Fe Ry. Co., 284 U.S. 370 (1932).

103. For example, rejection would follow a finding of rate-bureau agreement "violation" which, in turn, would be made after a "full hearing." Arizona Grocery characterized the ICC in retroactively awarding reparations as acting in a "quasi-judicial" capacity. 284 U.S. at 389.

104. An administrative action by HHS of the same species as the one at issue in American Trucking was characterized in Bowen v. Georgetown University Hospital, 488 U.S. 204, 215 (1988), as a retroactive rnle. See infra text accompanying notes 138-64.

105. American Trucking, 467 U.S. at 364-65.

106. Id. at 365 (quoting Trans Alaska Pipeline Rate Cases, 436 U.S. 631, 655 (1978)).

107. Id. at 367 .

108. Id. at 365 (citing American Trucking Associations, Inc. v. United States, 344 U.S. 298, 309 11 (1953)) 
Court neither discussed nor cited statutory retroactivity cases. The Court required something that approached a strong showing of need by the regulatory agency, a need that the Court cast in terms of achieving a legitimate statutory purpose. ${ }^{109}$ In that regard, Addison and American Trucking appear similar. Yet neither decision required the existence of clear statutory language as a prerequisite of retroactive rulemaking authority.

Lower federal courts have also dealt with the problem of retroactive agency rules. An examination of cases in the district and circuit courts produces a clearer picture of the pre-Bowen constraints on agency discretion in promulgating rules with retroactive effect.

\section{Retroactivity in the Lower Courts Prior to Bowen}

In dealing with retroactivity problems, the lower federal courts have relied on Thorpe and Greene to determine the validity and the permissible scope of administrative rules. Predictably, the courts have not viewed Thorpe as necessarily linited to situations where a new regulation takes effect during the litigation. However, the lower federal courts have frequently rebutted a presumption of retroactivity based on the impact on the private interests at stake.

The Department of Health and Human Services (and its predecessor, the Department of Health, Education and Welfare) has been by far the agency most frequently involved in reported cases that deal with allegedly retroactive rules. For example, in Colyer v. Harris, the Social Security Administration (SSA) denied the plaintiff's claim for benefits, basing the denial on the agency's apphication of medical-vocational rules that were adopted by the SSA after the clain thad been initially filed and determined by an administrative law judge (ALJ). ${ }^{110}$ In renianding the case to the agency because of an inadequate record, the district court confronted the question of the permissible retroactivity of the new regu-

109. See id. at 365-71 (using such terms as "necessary" and "only feasible"). In evaluating the ICC's arguments in favor of the tariff rejection power, based in part on the "inadequacy" of express statutory authority, the Court observed: "In another field, the inadequacy of an agency's express statutory authority might be secn as evidence that Congress intended for the agency not to possess more adequate powers." But in the ICC context, the Court said this negative implication could not be drawn because the statute at issue provided that "[e]numeration of a power of the Commission in this subtitle does not exclude another power the Commission may have in carrying out this subtitle." Id. at $369 \mathrm{n} .11$. Does this footnote therefore suggest that the general approach of American Trucking should be seen as irrelevant in the context of retroactivc agency rulemaking? No, for a variety of reasons. The discussion just quoted was reserved for a footnote and was used as a response to a particular argument advanced to support implied agency power; it assumes a concession that there is a lack of agency power-a concession which is irrelevant where the very issue is the scope of "express" agency power.

110. 519 F. Supp. 692, 694-95 (S.D. Ohio 1981). 
lations. After first citing Greene and Thorpe, the court adopted and applied the presumption in favor of retroactivity. ${ }^{111}$ The court read the Adininistrative Procedure Act definition of the term "rule"112 as an attempt to distinguish between rulemaking and adjudication and not to bar retroactive application of rules. ${ }^{113}$ Ultimately, however, the court in $\mathrm{Col}$ yer permitted retroactive application of only those rule provisions which benefited the claimant and disallowed it where "manifest injustice" to the claimant would result. 114

Similarly, the Fourth Circuit applied the Thorpe canon in Coe v. Secretary of HEW. ${ }^{115}$ In Coe, the administrator of a patient's estate sued to recover medicare benefits for services provided by a nursing hoine. Congress and HEW made various statutory and regulatory changes after the services had been provided, some favoring and some disadvantaging the claimant. The court-citing Greene, Thorpe, and Bradley-applied the statutory changes retroactively when they were to the claimant's advantage and found manifest injustice with respect to the regulatory changes that disadvantaged the claimant on the basis of the existence of a "matured" right to reimbursement."16 Thus, the pattern that einerges from these cases is that a rule which benefits a claimant may be applied retroactively if retroactive effect is consistent with the purposes of the program.

This pro-claimant approach was followed in Daughters of Miriam Center for the Aged v. Mathews. ${ }^{117}$ In Daughters of Miriam Center, a skilled nursing facility challenged the application of a Medicare regulation that purported to recapture excessive depreciation allocated and paid as reimbursement during prior years. ${ }^{118}$ Conceding that statutory authorization for retroactive application of the regulation existed, the court brushed aside the agency's own interpretation of the regulation as retroactive and noted that agencies lack political accountability. ${ }^{119}$ The court itself balanced, $a$ la Chenery II, the public and private interests at stake, ultimately finding that retroactivity was not justified. ${ }^{120}$

111. Id. at $697-700$.

112. The Administrative Procedure Act defines a rule as a "statement of general or particular applicability and future effect." 5 U.S.C. $\S 551(4)$ (1988).

113. Coyler, 519 F. Supp. at 698-99.

114. Id. at $700-01$.

115. 502 F.2d 1337 (4th Cir. 1974).

116. Id. at 1340. The regulatory changes in Coe had apparently been adopted prior to the adjudication.

117. 590 F.2d 1250 (3d Cir. 1978).

118. Id. at $1252-53$.

119. See id. at $1256-61$.

120. See id. at 1260-63. 
Cost reimbursement rules were also at issue in Saint Francis Memorial Hospital v. Weinberger. ${ }^{121}$ A Medicare provider sued to obtain reimbursement for interest payments it had made for three years on loans for construction of a replacement hospital facility. The agency denied the claim on the basis of a regulation, adopted after the provider's payment of the interest, which directed that such payments be "capitalized." Citing Greene for its protection of "vested rights" and then Thorpe for the "manifest injustice" exception to retroactivity, the court rejected retroactivity. ${ }^{122}$

Application of the Greene and Thorpe precedents does not, however, invariably result in a judgment unfavorable to the government. For example, in Azodi v. INS, an Iranian national applied to the Immigration and Naturalization Service (INS) to change her non-immigrant status from visitor to student. ${ }^{123}$ INS denied the petition based in part on a regulation specifically dealing with Iranian nationals that the agency adopted after the filing of Ms. Azodi's petition. Citing Thorpe as standing for the "general rule" that a court must apply the law in effect at the time it renders a decision, regardless of when the change of law occurs, the district court upheld the retroactive application in this case and found no "vested rights" at issue. ${ }^{124}$ Granting that a change in non-iminigrant status was "purely a inatter of discretion," the court found no "manifest injustice" given Congress' plenary power in the immigration area. ${ }^{125}$

Likewise, the government prevailed in Maxcell Telecom Plus, Inc. v. FCC. ${ }^{126}$ The FCC abandoned its use of comparative hearings to award licenses for cellular telephone service in small markets and substituted a lottery due to the large demand for the service and the large number of coinpeting firıns. ${ }^{127}$ This policy change was accomplished through rulemaking procedures. The FCC applied the new lottery procedures to a pending application, and one provider challenged the action as impermissibly retroactive. Applying the Chenery II and Retail, Wholesale balancing test, the D.C. Circuit ${ }^{128}$ upheld the agency's decision and found

121. 413 F. Supp. 323 (N.D. Cal. 1976).

122. Id. at $332-35$.

123. 515 F. Supp. 712 (S.D. Ohio 1981).

124. Id. at 714 .

125. Id. at 714-15.

126. 815 F.2d 1551 (D.C. Cir. 1987).

127. Id. at 1554 .

128. Several months later, the same court struck down the Bowen rule on the basis of the APA. See Georgetown Univ. Hosp. v. Bowen, 821 F.2d 750 (D.C. Cir. 1987), aff'd, 488 U.S. 204 (1988). The panel in Maxcell was comprised of Judges Bork (who wrote the unanimous opinion), Buckley, and Greene (a district judge sitting by designation). The panel in Bowen consisted of Judges Edwards (who wrote the unanimous opinion), Starr, and Swygert (a senior court of appeals judge 
statutory authority for the "retroactivity."129 The court emphasized the small magnitude of the cognizable impact on the applicant, prior notice of the possibility of a change in policy, and the need for efficient allocation of licenses. ${ }^{130}$ One view of Maxcell is that the case did not present facts sufficient to meet Thorpe's "manifest injustice" exception given those circumstances. ${ }^{131}$

Several cases have dealt with the issue of retroactivity of a substitute agency rule that was adopted following the invalidation of a previous regulation. For example, in Cumberland Medical Center v. Secretary of HHS, a medicare malpractice insurance cost-reimbursement rule adopted in 1979 was invalidated on substantive grounds. ${ }^{132}$ The agency later adopted a new version of the rule and made it retroactive to 1979, but in Mason General Hospital v. Secretary of HHS, the Sixth Circuit found the retroactivity impermissible. ${ }^{133}$ In denying retroactivity, the court reformulated the Retail, Wholesale test to deal with the peculiar

sitting by designation). Although the precise type of retroactive effect was different in each (in Bowen, an attempt to recoup reimbursed moneys, and in Maxcell, the application of a new rule to pending applications), the same problems of reliance are at the heart of both. See supra text accompanying notes 22-25 and infra text accompanying note 286.

129. Maxcell, 815 F.2d at 1554.

130. Id. at 1557.

131. In cases other than Maxcell, whether in construing the scope of agency regulations or in determining their validity, courts have referred to and purported to apply the factors listed in Thorpe as relevant to a finding of "manifest injustice," the Chenery II test and/or its Retail, Wholesale elaboration. See, e.g., Alaskan Arctic Gas Pipeline Co. v. United States, 831 F.2d 1043, 1050 (Fed. Cir. 1987) (invalidating application of regulations to recover processing costs of applications for gas pipeline rights-of-way across federal lands); Bedford County Memorial Hosp. v. Health and Human Servs., 769 F.2d 1017, 1020 (4th Cir. 1985) (invalidating HHS medical malpractice reimbursement rule); Mobil Oil Corp. v. Department of Energy, 678 F.2d 1083, 1088-89 (Temp. Emerg. Ct. App. 1982) (retroactive promulgation of mandatory petroleum price regulations invalidated); Summit Nursing Home, Inc. v. United States, 572 F.2d 737, 742 (Ct. Cl. 1978) (HHS depreciation recapture regulation upheld); Anderson, Clayton \& Co. v. United States, 562 F.2d 972, 984 (5th Cir. 1977) (upholding retroactivity of Treasury regulation dealing with foreign tax credit), cert. denied, 436 U.S. 944 (1978); Maceren v. District Director, INS, 509 F.2d 934, 939 (9th Cir. 1974) (refusal to permit retroactive application of regulation providing a one-year period of validity for labor certification); Certified Color Indus. Comm. v. Secretary of Health, Educ. and Welfare, 283 F.2d 622, 626 (2d Cir. 1960) (upholding revocation of color certifications); Leila Hosp. \& Health Center v. Bowen, 661 F. Supp. 397, 402 (W.D. Mich. 1987) (court upheld wage index regulation later invalidated in Bowen), rev'd, 873 F.2d 132 (6th Cir. 1989) (on basis of Bowen); American Fed'n of Gov't Employees v. Nimmo, 536 F. Supp. 707, 717 (E.D. Va. 1982) (retroactive application of regulations requiring reimbursement of costs of nonservice-connected medical care), vacated on merits but aff'd on other grounds, 711 F.2d 28 (4th Cir. 1983); White v. Califano, 473 F. Supp. 503, 506 (S.D. W. Va. 1979) (rejecting application of new regulations to disability insurance claim); Johnson v. Finch, 328 F. Supp. 1169, 1174 (E.D. La. 1971) (claim for emergency inpatient hospital services would not be governed by new Social Security Administration regulations); Blau v. Hodgkinson, 100 F. Supp. 361, 372 (S.D.N.Y. 1951) (SEC rule implementing section 16 of the Securities Exchange Act applied retroactively).

132. 781 F.2d 536, 538 (6th Cir. 1986).

133. 809 F.2d 1220, 1227-28 (6th Cir. 1987). 
situation at issue. The Mason court stated the relevant inquiries for permissible, statutorily authorized retroactive rulemaking include the following:

1. the degree of capriciousness or abuse of discretion exhibited by the agency in the promulgation of the initial rule;

2 . the existence and duration of a prior or settled regulation or practice, and the extent to which the initial invalidated rule constituted a substantial change in such settled practice; and,

3. the extent to which the change embodied in the initial invalidated rule was integral to the effectuation of the statutory purpose. ${ }^{134}$

In adopting this approach, the court was motivated by a concern that too lax a test for permissible retroactivity would undercut the protections of the APA. ${ }^{135}$ More specifically, the public participation and agency explanation requireinents of the APA ${ }^{136}$ are intended, among other things, to bring about thoughtful agency decisionmaking which has the benefit of information not possessed by the agency. ${ }^{137}$ Failure to adhere to procedural requirements of the APA inay undermine these purposes. Even if the agency in its subsequent rulemaking effort complies with APA procedures, notice-and-comment proceedings may not produce the desired effects in view of the agency predisposition to readopt the invalidated rule. In this context, permitting retroactive application of the second rulemaking effort may remove some incentive for compliance with the APA in the initial proceeding.

Mason involved a scenario that was similar to Bowen, where the reformulated balancing test of Retail, Wholesale also suggested that retroactivity should be rejected. The Bowen Court did not, however, adopt the balancing approach to the resolution of the retroactivity issue. Rather, it dealt with the issue as solely a matter of statutory interpretation.

\section{E. The Bowen Case}

1. Interpretation of the Medicare Act: Justice Kennedy's Opinion for the Court. Under the Medicare program, health care providers are reimbursed by the government for the various expenses they incur in furnishing medical services. The Secretary of HHS has the general authority to adopt rules that limit the levels of reimbursement. ${ }^{138}$

In 1981, the Secretary issued a cost-limit schedule that changed the method for calculating the "wage index," a factor used to reflect the sal-

134. Id. at 1228 .

135. Id. at 1231 .

136. 5 U.S.C. $\$ 553(b)$-(c) (1988).

137. See, e.g. Connecticut Light and Power Co. v. NRC, 673 F.2d 525, $530-31$ (D.C. Cir. 1982).

138. 42 U.S.C. $\S 1395 \times(v)(1)(A)(1988)$. 
ary levels of hospital employees. One change eliminated the wages paid by federal government hospitals as a factor in the index. In 1983, in a suit that involved various District of Columbia hospitals, the district court invalidated the new rule on the basis of an HHS violation of the notice-and-comment provisions of the APA. ${ }^{139}$ The Secretary conceded the invalidity of the rule and reinbursed the hospitals on the basis of the pre-1981 wage index. Then, in 1984, HHS coinmenced a rulemaking proceeding to reissue the 1981 rule with retroactive effect. Because of various statutory changes in the Medicare Act, HHS limited the effect of the proposed rule to a fifteen-month period that coinmenced on July 1, 1981. Following public notice-and-cominent procedures, HHS adopted the proposed regulation and proceeded to recoup sums paid as a result of the earlier district court decision. ${ }^{140}$ Hospitals that had benefited in excess of $\$ 2$ million from the earhier judicial action sued to invalidate the new rule. Both the district court (applying the Retail, Wholesale test) ${ }^{141}$ and the D.C. Circuit (on the basis of the Medicare Act and the APA) struck down the regulation. ${ }^{142}$ The Supreme Court affirmed.

At the beginning of his opimon for a unanimous court, Justice Kennedy succinctly described the general contours of the analysis deemed dispositive of the issue raised by retroactivity:

It is axiomatic that an administrative agency's power to promulgate legislative regulations is limited to the authority delegated by Congress. In determining the validity of the Secretary's retroactive costlimit rule, the threshold question is whether the Medicare Act authorizes retroactive rulemaking.

Retroactivity is not favored in the law. Thus, congressional enactments and administrative rules will not be construed to have retroactive effect unless their language requires this result. By the same principle, a statutory grant of legislative rulemaking authority will not, as a general matter, be understood to encompass the power to promulgate retroactive rules unless that power is conveyed by Congress in express terms. Even where some substantial justification for retroactive rulemaking is presented, courts should be reluctant to find such authority absent an express statutory grant. ${ }^{143}$

139. District of Columbia Hosp. Ass'n v. Heckler, No. 82-2520, slip op. at 19 (D.D.C. Apr. 29, 1983) (cited in Georgetown Univ. Hosp. v. Bowen, No. 85-1845, slip op. at 1 (D.D.C. Apr. 11, 1986) (1986 WL 53398)).

140. 49 Fed. Reg. 46495 (1984).

141. Georgetown Univ. Hosp. v. Bowen, No. 85-1845, slip op. at 8-9 (D.D.C. Apr. 11, 1986) (1986 WL 53398).

142. Georgetown Univ. Hosp. v. Bowen, 821 F.2d 750 (D.C. Cir. 1987), aff'd, 488 U.S. 204 (1988).

143. Bowen, 488 U.S. at 208-09 (1988) (citations omitted). The Court here takes an approach similar to that taken by Professor Kenneth Culp Davis:

Although the argument is plausible that legislative rules may be retroactive whenever a statute may be, since the fairness or unfairness is the same and judicial ideas of fairness are 
The Court cited Greene ${ }^{144}$ and other cases ${ }^{145}$-all of which dealt with the issue of retroactivity in the context of construing statutes or regulations-to support its reasoning. Justice Kennedy, however, did not discuss Addison. Thorpe, or the line of cases that followed Thorpe.

The Court then turned its attention to the language and history of the Medicare Act, including House and Senate committee reports and prior administrative constructions. Rather than showing an absence of congressional concern for the retroactivity issue, these sources convincingly indicated that Congress had in fact considered the issue and limited the Secretary's discretion to prospective cost-limit rules. ${ }^{146}$

The Court finally considered the arguinent that judicial invalidation of a prospective rule presented a special case with respect to retroactivity: The first ruleinaking allegedly put the hospitals on notice, thus deflating any argunent premised on unfair surprise. HHS enbellished this arguinent by raising the specter of frustration of "congressional intent and important adıninistrative goals" if curative retroactivity were not permitted. ${ }^{147}$ Justice Kennedy's response to this was brief: Whatever weight the contentions might have in other contexts, "they need not be addressed here. ... [because the case was] resolved by the particular statutory scheme in question. Our interpretation of the Medicare Act compels the conclusion that the Secretary has no authority to promulgate retroactive cost-limit rules." 148

Even though there was speciflc evidence of congressional intent to deny retroactive rulemaking power for cost-himit mles, the Court went beyond this to impose a general clear statement barrier to federal agency adoption of retroactive legislative rules. In the process, the Court appeared to reject arguments for retroactive effect phrased in terms of "need." Such arguments inight point to substantial cost or revenue savings for the government or reduced dangers to public health; problems

decisive, rules differ in two main respects-agencies have no powers except those conferred and courts are reluctant to imply power to issue retroactive rules, and courts give greater deference to judgments of legislative bodies than to judgments of agencies. The ideal might be to tolerate retroactive rules only when they are specifically authorized by a statute, but courts' holdings fall well short of that ideal.

2 K. Davis, Administrative Law Treatise $\S 7: 23$, at 109 (2d ed. 1978).

144. Bowen, 488 U.S. at 208.

145. The Court cited the following cases: Claridge Apartments Co. v. Commissioner, 323 U.S. 141 (1944) (interpretation concerning retroactive application of Bankruptcy Act); Miller v. United States, 294 U.S. 435 (1935) (interpretation concerning retroactive application of a Veterans Administration regulation); United States v. Magnolia Petroleum Co., 276 U.S. 160 (1928) (retroactivity of a revenue statute); Brimstone R.R. \& Canal Co. v. United States, 276 U.S. 104 (1928) (retroactivity of an 1CC administrative order). Bowen, 488 U.S. at 208.

146. Bowen, 488 U.S. at 209-16.

147. Id. at 215 .

148. Id. (emphasis added). 
that might be avoided or mitigated by retroactivity. But even these factors would be unavailing in the face of a general statutory ban on retroactive agency rules. Although Justice Kennedy did not find such a prohibition, Justice Scalia beheved he had discovered one.

2. The Administrative Procedure Act: Justice Scalia's Concurrence. Justice Scaha's concurrence in Bowen criticized the Court for failing to rely on the independent significance of the APA. ${ }^{149}$ However, one aspect of Justice Scalia's approach to the problem of retroactive legislative rulemaking is similar to the approach expressed by Justice Kennedy: Retroactive legislative rulemaking, according to Justice Scalia, is permissible if there is "soine special congressional authorization," an authorization which could occur "implicitly."150 In adopting this approach concurrently with his emphasis on the APA, Justice Scalia's position seemed to be that, as a matter of law, the APA limits agencies' discretion and prevents them from adopting retroactive legislative rules without congressional approval. In support of this conclusion, he relied on the definition of "rule" in the APA 151 and the 1947 Attorney General's Manual on the Admimistrative Procedure Act, ${ }^{152}$ both of which refer to future effect. To allow retroactive legislative "rules" within the meaning of the APA would, according to Justice Scalia, "destroy the entire dichotomy upon which the most significant portions of the APA are based."153 As in a number of recent Supreme Court opinions, ${ }^{154}$ Justice Scalia purportedly based his argument on the "plain meaning" of the statute at issue (in

149. Id. at 216-25 (Scalia, J., concurring).

150. Id. at 223. Justice Kennedy's emphasis on "express" language and Justice Scalia's acceptance of "implied" authorization may be significant in some cases, however. At the same time, "implications" can be deemed "clear" or "unclear." But see infra text accompanying notes 154 \& 186.

151. 5 U.S.C. $\$ 551(4)$ (1988).

152. United States Department of Justice, Attorney General's Manual on the Administrative Procedure ACT (1947) [hereinafter Attorney General's MaNual].

153. Bowen, 488 U.S. at 216.

154. See, e.g., Griffin v. Oceanic Contractors, Inc., 458 U.S. 564 (1982) (double payment penalty imposed on vessel owners failing to pay seamen wages promptly after their discharge beeause the plain meaning of the statute left no room for discretion); see also Eskridge, The New Textualism, 37 UCLA L. REv. 621, 623, 651 (1990) (referring to cases in which Justice Scalia, in concurring and dissenting opinions, "criticized the Court for relying on legislative history to confirm or rebut the apparent plain meaning of a statute"); Eskridge \& Frickey, Statutory Interpretation as Practical Reasoning, 42 STAN. L. REv. 321, 340 n.71 (1990) (pointing out Justice Scalia's affinity for the "plain meaning" rule); Sunstein, Interpreting Statutes in the Regulatory State, 103 HARV. L. REv. 405, 415, 429 n.85 (1989) (discussing Justice Scalia's hostility to complexity); Note, Intent, Clear Statements and the Common Law: Statutory Interpretation in the Supreme Court, 95 HARv. L. Rev. 892 (1982) (discussing the failure of the clear-statement model to provide a rational foundation for statutory interpretation). 
this instance, the APA). Justice Scalia argued, "That is what the APA says, and there is no reason to think Congress did not mean it."15s

For additional support of his view, Justice Scalia pointed to Chenery $I I$ 's reference to rulemaking as prospective and the opinions in $N L R B v$. Wyman-Gordon Co., 156 which suggest that "prospective" adjudication is "rulemaking" within the meaning of the APA. Justice Scalia then distinguished Addison on the grounds that it involved interpretative, not legislative, rules or, at best, "implicit" statutory authorization for retroactive rulemaking. ${ }^{157}$ According to Justice Scalia, although Congress can constitutionally adopt retroactive statutes, this fact does not coinpel the conclusion that Congress' delegates-administrative agencies with general rulemaking power-can do the same. ${ }^{158}$ This position naturally followed from what Justice Scalia perceived as the general "disfavor" of retroactivity in the law.

Construing the APA as involving a presuinption agaimst retroactivity will not, in Justice Scalia's view, have dire consequences. First of all, the Government allegedly cited "only one holding and one alternative holding (set forth in a footnote) sustaining retroactive regulations" during the forty years since the APA was enacted. Accordingly, such rules "are evidently not a device indispensable to efficient government."159 At any rate, Justice Scalia suggested that if retroactivity is desired, an agency can develop such a poticy through the adjudicatory mode. ${ }^{160}$ Or, on an ad hoc basis, an agency can ask Congress for the power to adopt retroactive rules. ${ }^{161}$ Moreover, such authority may already exist iniplicitly in situations in whicli congressional deadlines exist for putting a regulatory structure in place. ${ }^{162}$

There may be other exceptional circumstances in Justice Scalia's view, that justify retroactive agency rules. Although Justice Scalia disapproves of HHS's curative power theory as threatering to make a mockery of the APA-since agencies would allegedly be free to violate the APA notice-and-comment mandates with impunity ${ }^{163}$-it is not clear to

155. Bowen, 488 U.S. at 224 (Scalia, J., concurring).

156. 394 U.S. 759 (1969) (plurality opinion); id. at 775 (Douglas, J., dissenting); id. at 780 (Harlan, J., dissenting).

157. Bowen, 488 U.S. at 222-23 (Scalia, J., concurring).

158. Id. at 223 .

159. Id. at 224 .

160. See id.

161. See id.

162. See id. If Congress has, for example, enacted a provision reqniring that certain regulations be adopted within six months, it might be argued that, if the designated agency inisses that deadline, the purposes of the statute reqnire retroactivity. If the pnrposes do require retroactivity, Congress "Inust have so intended" to authorize retroactivity in the circunstances.

163. See Bowen, 488 U.S. at 225 (Scalia, J., concurring). 
what extent Justice Scalia, unlike the majority, would be inclined to accept slowings of "need" as a surrogate for the congressional intent to give an agency the power to promulgate retroactive rules. ${ }^{164}$

In short, all of the Bowen opinions focused on the issue of statutory authority for retroactive agency action. Justice Kennedy found linits on HHS's retroactive rulemaking authority im the Medicare Act and the new clear statement canon. Justice Scalia claimed that the APA provided an additional limit. Both the clear statement canon and Justice Scalia's interpretation of the APA may prove to be inisguided graspings for external, formal limits on retroactivity. The Court failed to specify a rationale for the proposed clear statement canon, and a satisfactory justification may be unavailable. Moreover, Justice Scalia's construction of the APA would unduly limit the applicability of notice-and-comment rulemaking. To those issues we now turn.

\section{A Critique of BoweN}

The use of clear statement canons of statutory interpretation is a well-established judicial device to force Congress to confront significant issues. Yet the invocation of these canons may be inconsistent with the principle of legislative supremacy in non-constitutional policymaking. In addition, they may create other undesirable effects. Accordingly, a clear statement approach requires careful consideration prior to its adoption, as well as express judicial explication of its bases. The Bowen opinion does not ineasure up to these standards. Moreover, the opinion is both at odds with other recent Supreme Court caselaw that deals witl the general scope of administrative agency statutory authority and unnecessarily linits agency flexibility in carrying out congressionally authorized programs. Many of the problems posed by Bowen are not susceptible to solution by narrowly construing the opmion so as to confine the impact of the clear statement canon.

Justice Scalia's interpretation of the APA's substantive effect-if accepted by the courts-threatens to raise an even more formidable barrier to retroactive rulemaking. However, an analysis of the text, context, and purposes of the APA demonstrate that his construction lacks merit.

\section{A. The Court's Opinion in Bowen}

1. Bowen's Inappropriate Use of a Clear Statement Approach. Federal administrative agencies originate solely from congressional delegations of power; thus questions of statutory authority provide a focus for judicial review of agency action. Accordingly, it is not useful to quib-

164. See supra text accompanying note 150 and infra text accompanying note 220 . 
ble with Justice Kennedy's starting point in Bowen-the threshold issue of whether the Medicare Act authorizes retroactive rulennaking. But his invocation of a clear stateinent canon is not sinilarly immune froin criticism.

Assuining Congress attenpted to deal with a particular issue, the clarity with which that intent is expressed may range from the unmistakable to non-existent. Lack of clarity inay reflect, among other things, Congress' intentional or unintentional failure to address a particular matter. ${ }^{165}$ Clear statement canons of statutory construction-which direct a particular result absent requisite precision of expression-act, in the instance of a failure by Congress to address the matter, as a true "gapfiller" by resolving the untouched issue one way or another. However, in situations in which congressional intent exists but is difficult to discover or document, a clear stateinent approach may lead to a result contrary to Congress' intent. ${ }^{166}$

Generally speaking, a clear statement canon reflects either assuinptions of how Congress actually operates or normative principles on how it should operate. ${ }^{167}$ In other words, the Court may be saying that Congress in fact uses precise language if it wants to achieve a certain result. 168 Alternatively, because of substantive policy or constitutional concerns, the Court may intend to direct Congress to speak clearly if it desires to achieve a particular result. ${ }^{169}$ In the first category of cases, the Court tries to effectuate congressional intent; in the second, it may defeat congressional intent and force the legislature to reenact the statute in a manner that satisfies the judicial standard.

Justice Kennedy's opinion in Bowen fails to disclose the basis for its clear stateinent canon. By noting that "[r]etroactivity is not favored in the law," 170 the Court may be indicating either that Congress generally does not desire retroactive effect or that Congress should not authorize it

165. See, e.g., Industrial Union Dep't, AFL-CIO v. American Petroleum Ins., 448 U.S. 607, 676-82 (1980) (Rehnquist, J., concurring) (striking down an OSHA restriction on benzene claiming that the plain meaning advocated by OSHA would violate congressional intent).

166. Luneburg, Justice Rehnquist, Statutory Interpretation, the Policies of Clear Statement, and Federal Jurisdiction, 58 IND. L.J. 211, 217 (1982). On clear statement approaches, see generally Eskridge, Public Values in Statutory Interpretation, 137 U. PA. L. REv. 1007, 1028-30 (1989) (comparing specific presumptions and clear statement rules); Farber, Statutory Interpretation and Legislative Supremacy, 78 GEO. L.J. 281, 284-87 (1989) (discussing họw judicial policymaking often results from judicial interpretations of ambiguous statutes and congressional directives).

167. See Luneburg, supra note 166, at 218-19.

168. See, e.g., Transcontinental and Western Air v. Civil Aeronautics Bd., 336 U.S. 601, 607 (1949) ("We cannot but feel that if the ratemaking power were to be put to such a novel use, the purpose would have been made clear.").

169. See Luneburg, supra note 166, at 219-21. See generally Sunstein, supra note 154, at $462-93$ (discussing interpretive principles that are used by the Court to determine statutory meaning).

170. Bowen v. Georgetown Univ. Hosp., 488 U.S. 204, 208 (1988). 
because of the problems of surprise which may have due process overtones. The two rationales for clear statement approaches may blend here as well as elsewhere. For example, as the Supreme Court and other courts construe statutes to avoid retroactivity, this approach becomes part of the legal context in which Congress operates and of which it is presumably aware-a background rule against which Congress legislates. On this theory, a lack of clarity on retroactivity may, therefore, be taken to evidence congressional intent to prohibit a retroactive effect.

One might argue that if prospectivity generally is associated with rules, then a grant of rulemaking power must be a grant of the power to act prospectively. Congress, however, sometimes acts retrospectively and-because agencies frequently act in Congress' stead-it is odd to assume that Congress did not authorize agencies to act retrospectively as well. Justice Scalia rejects this analogy on the basis of his interpretation of the APA and on what he views as the disfavor in which retroactive legislation has been held. ${ }^{171}$ But to reject the legislative analogy on the basis of the law's disfavor of retroactivity is at best a weak reed; that disfavor has not prevented retroactive legislative policymaking. Furthermore, given Thorpe, it is difficult to argue that Congress must have intended to limit general grants of rulemaking power to prospective rules. To assert, as Justice Scalia does, that "[i]t is entirely unsurprising, therefore, that even though Congress wields such power itself, it has been unwilling to confer it upon the agencies"172 assumes what is to be proved. Is it plausible to assume that congressional silence or a lack of clarity means that Congress does not approve of an agency engaging in retroactive rulemaking, even when that action will reasonably promote congressional goals? Such a proposition lacks empirical support.

One criticism of Bowen, therefore, is that the Court may disallow retroactive rulemaking even in cases where Congress intended it. Moreover, by saying that "[e]ven where some substantial justification for retroactive rulemaking is presented, courts should be reluctant to find such authority absent an express statutory grant,"173 Justice Kennedy's opinion suggests that a mere showing of need for retroactivity will not necessarily be deemed sufficient as a basis for authority to act retroactively. ${ }^{174}$ And yet in American Trucking, the Court upheld the validity of an

171. See id. at 223. Justice Scalia also noted that the constitutionality of retroactive legislation "has been conditioned upon a rationality requirement beyond that applied to other legislation." Id. This is a different standard, but not a higher one. See supra note 49.

172. Id. at 224 .

173. Id. at 208-09.

174. In Dellmuth v. Muth, 491 U.S. 223 (1989), the Court held that the clear statement by Congress to abrogate state immunity under the eleventh amendment "must be both unequivocal and textual." Id. at 230. It will generally not be found in legislative history. 
agency action which was in practical effect equivalent to retroactive rulemaking on a showing of legitimate need by the agency to achieve statutory mandates. ${ }^{175}$ Addison similarly indicated that retroactive rulemaking could be sustained on a showing of need. ${ }^{176}$

Subversion of legislative intent through a clear stateinent approach can be justified when an important judicial, legislative, or constitutional policy is at stake. ${ }^{177}$ For example, in the federal preemption area, ${ }^{178}$ there is reason to demand statutory clarity to force Congress to confront and resolve potential state/federal conflicts directly. ${ }^{179}$ It is not clear, however, from a normative judicial or constitutional perspective that retroactivity should be treated like federal preemption. Although problerns of reliance and undue surprise inay arise froin retroactivity, purely prospective statutes and administrative rules may have a similar practical impact. ${ }^{180}$ Thus, what purport to be the normative underpinnings of a clear statement approach to retroactivity may evaporate under close scrutiny. From a judicial policy standpoint, a significant portion of the caselaw-the Thorpe-line of cases-treats retroactivity as the norm. And, the constitutional benchmark for retroactivity approximates a "inere" rationality standard that runs counter to the notion of crafting a special interpretive rule for issues of retroactivity. ${ }^{181}$

Justice Kennedy's opinion suggests that in determining whether the Bowen clear statement requirement is met, the agency's interpretation of its own authority may have some weight. See Bowen, 488 U.S. at 211-12 (in construing the one provision of the Medicare Act which expressly permitted "retroactive corrective adjustments" as limited to case-by-case adjudication, the agency's consistent (up to the Bowen litigation itself) interpretation was given weight); see also id. at 213-14.

175. See supra text accompanying notes 101-09.

176. See supra text accompanying notes $94-100$.

177. See, e.g., Luneburg, supra note 166, at 220; Eskridge, supra note 166, at 1029, 1045, 1051.

178. See, e.g., New York Dep't of Social Servs. v. Dublino, 413 U.S. 405, 413-14 (1973) (denying the preemption of New York State Work Rules without "direct and unambiguous language"). In Skinner v. Mid-America Pipeline, 490 U.S. 212 (1989), the Court found that delegation of taxing power to an agency was not subject to a more stringent constitutional test than ordinary delegations. Id. at 222-23. At the same time, it demanded that Congress be clear in its delegation of that power. See id. at 224. The Court does not explain how a non-demanding constitutional standard and a demanding statutory interpretative approach can be reconciled (the same problem presented in the retroactivity area). It could be argued, however, that constitutional history ("no taxation without representation") and the origination clause, U.S. CONST. art. I, $\S 7$ (bills for raising revenue must originate in House of Representatives) suggest that members of Congress should clearly authorize taxation of a particular kind (via delegation) so that they have to take the "political heat" that may be generated by the imposition or potential imposition of new taxes. See J. FrEEDMAN, CRISIS AND LEGITIMACY 80-88 (1978).

179. See Luneburg, supra note 166, at 221.

180. See Graetz, Legal Transitions: The Case of Retroactivity in Income Tax Revision, $126 \mathrm{U}$. PA. L. Rev. 47, 49-63 (1977).

181. It might be argued that the constitutional prohibitions on takings, impairment of contracts, and ex post facto laws, along with the basic due process concept of adequate notice, combine to create a strong constitutional "policy" to protect reasonable reliance interests. Yet, as the text notes, 
2. Bowen and Chevron: Inconsistent Interpretive Approaches. When Congress leaves the issue of retroactivity unaddressed, the Bowen approach may nevertheless appear appealing. The argument goes as follows: If an agency possesses only those powers granted by Congress, and if Congress did not intend to grant a particular power, then the agency does not have the power. Historically, however, the lack of statutory clarity has not forced the courts to restrict agency action. ${ }^{182}$ For example, the lime of precedents culmmating with Chevron, U.S.A., Inc. v. NRDC, Inc., 183 conceded to agencies the power to fill statutory "gaps," both large and small. Chevron spoke im terms of implied, but essentially fictive, delegations of power, ${ }^{184}$ and upheld reasonable agency assertions of power withm unspecified limits-unless Congress has "directly spoken to the precise question at issue" and denied the power to the agency. ${ }^{185}$ Bowen, in contrast, negates reasonable agency assertions of a particular type of power unless Congress has expressly (or "clearly") granted that authority to the agency. ${ }^{186}$ Thus, if the Bowen clear statement principle

the unevenness of the implementation of that "policy" in American law weakens the argument in favor of its treatment as an appropriate normative foundation for a clear statement approach.

182. The APA, in 5 U.S.C. $\S 558(5)$ (1988), incorporates the delegation theory: "A sanction may not be imposed or a substantive rule or order issued except within jurisdiction delegated to the agency and as authorized by law." However, in commenting on this provision (then section 9(a)), the ATTORNEY GENERAL's MANUAL noted: "Many agencies' powers are very clear; they are set forth specifically in the act creating the agency. Still other powers may be readily inferred from the framework of the act creating the agency or may be logically necessary for the conduct of the powers granted to the agency." ATTORNEY GENERAL's MANUAL, supra note 152, at 88-89.

183. 467 U.S. 837 (1984).

184. See Luneburg, Judicial Review of Agency Statutory Interpretation: An Introduction, 2 ADMIN. L. REv. 243, 252-53 (1988); see also Sunstein, supra note 154, at 445.

185. Chevron, 467 U.S. at 842 . Although Chevron and some subsequent opinions relying on it (e.g. Sullivan v. Zebley, 110 S. Ct. 885, 897 (1990) (White, J., dissenting)) refer to a search for "clear congressional intent," Chevron need not be interpreted to require particular clarity by Congress to avoid acceptance of an agency's view. See Luneburg, supra note 184, at 246 n.19. Rather, the reviewing court must first independently evaluate textual and contextual materials and, if the court feels confident it has discovered congressional intent, contrary agency views must be disregarded. For a recent case that arguably confirms this reading of Chevron, see Dole v. United Steelworkers, 110 S. Ct. 929 (1990).

186. Justice Kennedy twice uses the word "express" to describe the requisite congressional delegation. See Bowen v. Georgetown Univ. Hosp., 488 U.S. 204, $208-09$ (1988). Other parts of the opinion might be construed to suggest that lack of "express" language may not be fatal. For exam. ple, he notes that "the absence of any express authorization for retroactive cost-limit rules weighs heavily against the Secretary's position." Id. at 214 (emphasis added). If "express" language were necessary, why would its absence not be dispositive, rather than merely "weigh[ing] heavily against" the agency's assertion of power? At the same time, Justice Kennedy also wrote opinions during the 1988 Term expressing adherence to the "plain meaning" rule, suggesting that his standard for "clarity" may be very high. See, e.g., Public Citizen v. United States Dep't of Justice, 491 U.S. 440, 468 82 (1989).

Chevron and Bowen mark opposite starting points in approaching the scope of agency authority. However, a formalistic reconciliation might nevertheless be possible. Chevron first requires a eourt to ask whether Congress has addressed the issue presented, using "traditional tools of statutory 
is to stand, the Court must make some attempt to square it with Chevron. ${ }^{187}$

\section{The Impact of Bowen on Agency Flexibility. Justice Kennedy} did not refer to Addison, American Trucking, ${ }^{188}$ or the Thorpe-line of cases in his opimion for the Court in Bowen. Thus, the clear statement approach articulated in Bowen fails to account for these past precedents. ${ }^{189}$ Furthermore, Bowen represented a shift to a broader arena from the earlier debate over whether the proper presumption was for or against the retroactive application of a statute or a regulation to a particular case. After Bowen, the presumption agamst retroactivity attaches to an agency's authority to adopt rules. In this context, a generally applied anti-retroactivity canon of interpretation creates distimctive difficulties for the implementation of congressional programs. Current delegations of legislative power to engage in rulemaking often amount to vaguely worded directions or authorizations to make policy throughout a wide spectrum of circumstances. Even when there is a delegation of some

construction." Chevron, 467 U.S. at 843 n.9. Interpretive canons are among such traditional toolsalthough often they are clumsy and wrong-headed. See generally R. Dickerson, THE INTERPRETATION AND APPLiCATION OF STATUTES 227-36 (1975). For a recent defense of the canons (or at least some of them), see Sunstein, supra note 154, at 451-60. The Bowen canon indicates that absent a "solid" basis evidencing a grant of retroactive authority, the conclusion, as a matter of law, is that Congress did not intend to grant that authority. In Chevron terms, Congress is deemed to have "directly spoken." Although an agency's interpretation of its authority might be "considered" and given some weight in determining whether that "solid" base exists, see supra text accompanying note 174 , it is only one among other factors, including text and legislative history, relevant to a final and independent judicial decision.

187. Bringing the Chevron and Bowen principles into harmony will prove particularly difficult for Justice Scalia, who believes that Chevron extends to matters of agency jurisdiction. See Mississippi Power \& Light Co. v. Mississippi ex rel. Moore, 487 U.S. 354, 380-82 (1988) (Scalia, J., concurring). Justice Scalia sees the Chevron principle as rooted in presumed congressional delegation. Scalia, Judicial Deference to Administrative Interpretations of Law, 1989 DUKE L.J. 511, 517. However, he suggests that Chevron represents "merely a fictional, presumed intent." Id. It is not clear, however, that the opposite presumption of Bowen, which he also accepts, is rooted in an accurate judgment of congressional operation. See supra text accompanying notes 171-72.

188. American Trucking, 467 U.S. 354 (1984), arguably involved the imposition of retroactive rules with a negative impact on the regulated, a pattern very similar to the circumstances of Bowen. The American Trucking Court ratified an assertion of retroactive agency power despite the Court's admission in American Trucking that Congress had not expressed its intent on the matter. The Court held that "the absence of express remedial authority" was not conclusive. Id. at 365; see also supra note 182. Admittedly, American Trucking might be construed to require a strong showing that a retroactive rule is needed to carry out statutory purposes. It is not clear, however, whether the Court meant to suggest in American Trucking that the same degree of need would be required in all instances, regardless of the breadth and impact of the agency action.

189. Justice Scalia searched for other arguments tied "to the basic structural legislation which is the embodiment of [general] principles" of administrative law to support the holding, Bowen, 488 U.S. 204, 216 (Scalia, J., concurring), although, as we shall see, his efforts to find them in the APA were to no avail. See infra text accompanying notes 198-220. 
specificity, the potential justifications for retroactivity may vary tremendously depending on the type of problem facing the agency. Despite the absence of clear congressional intent to permit retroactivity, an agency may be able to cite a number of statutory and administrative needs that may be achieved by allowing retroactivity of particular rules. A high standard of need might be required by the courts when the rule impacts on important constitutional values or very significantly affects private parties. If the impact on regulated interests is small, however, the group's reliance interests are insignificant, or the degree of retroactivity is minor, then greater leeway may be justifiable. ${ }^{190}$ Preventing rule-by-rule analysis of the permissibility of retroactivity eliminates an important degree of administrative discretion-which Chenery II recognized as essential. ${ }^{191}$ Yet the clear statement canon of Bowen and its shift away from an inquiry into "need" may have exactly this result.

There is a constant tension in the law between the need for clear guidance in the private and public sectors in order to determine what is permissible and the desire to maintain flexibility to deal appropriately with individual situations. ${ }^{192}$ Bowen promises clear guidance: Formal retroactivity is only permissible if Congress has clearly provided for it by statute. A case-by-case balancing analysis inevitably creates uncertainty and accompanying costs for both the regulators and the regulated. Yet the legal system tolerates retroactivity to such a degree, whether in the adjudicative ${ }^{193}$ or legislative contexts, ${ }^{194}$ that the risk of adverse effects on reliance interests is always present and substantial. Accordingly, it is difficult to believe that the aggregate costs of uncertainty are increased significantly by permitting agencies to adopt retroactive rules when the benefits of retroactivity outweigh the costs even in the absence of clear delegations of authority. This is particularly true because formally retro-

190. The Chenery II, Retail, Wholesale, and even the constitutional due process tests for retroactivity allow such flexibility and some court deference to the agency's weighing of relevant considerations. See, e.g., Retail, Wholesale and Dep't Store Union v. NLRB, 466 F.2d 380, 390 (D.C. Cir. 1972).

191. See Chenery II, 332 U.S. 194, 202 (1947) ("But any rigid requirement [for prospective rulemaking] would make the administrative process inflexible and incapable of dealing with many of the specialized problems which arise.").

192. See, e.g., Diver, The Optimal Precision of Administrative Rules, 93 YALE L.J. 65 (1983).

193. Some agencies use the adjudicative context as their principal policymaking mode. The $\mathrm{Na}$ tional Labor Relations Board is an example. See, e.g., Peck, The Atrophied Rulemaking Powers of the National Labor Relations Board, 70 YALE L.J. 729 (1961). In the wake of Bowen, more agencies may be attracted to adjudication as the primary form of policymaking. See infra text accompanying notes 306-11.

194. See, e.g., Graetz, supra note 180, at 57-60 (arguing that any change in law affects taxpayers' expectations). 
active rules are only infrequently adopted, ${ }^{195}$ and their numbers are not likely to increase substantially even with the adoption of a balancing test.

In short, if generally applied to statutory grants of admmistrative agency rulemaking power, the Bowen canon may eliminate an important element of agency discretion. Yet the Court makes no real effort to explain the basis for this interpretive approach. Moreover, it is not at all clear that protection of reliance interests, which usually underlies hostility to retroactivity, is sufficient to support the Bowen canon. Given the importance of agency flexibility in rulemaking, it may be expected that attempts will be made to construe Justice Kennedy's opimion in such a way as to limit the impact of Bowen. 196

\section{B. Limiting the Impact of Bowen}

1. Relegating the Clear Statement Canon to Dictum. Bowen announced a clear statement canon when it was unnecessary to rely on such a canon. Sufficient evidence of congressional intent existed to prohibit HHS from utilizing retroactive rulemaking in a Bowen-like context. Moreover, in the absence of evidence of congressional intent, the extent

195. See infra text accompanying notes 261-90.

196. A Chenery II/Retail, Wholesale-type balancing with the addition of a non-retroactivity presumption might lead to the same results as the Bowen canon. However, it is unlikely that the Bowen Court intended an implicit adoption of the Chenery II/Retail, Wholesale test. If the Court were determined to explain the invalidation of the HHS rule without relying on the specific congressional intent underlying the Medicare Act, then it had at least three apparent options: the clear statement canon; Justice Scalia's APA construction; or a simple finding under Chenery II/Retail, Wholesale that the adverse impact of retroactivity exceeded the benefits. Even Justice Scalia concedes that the Bowen canon and the APA argument have the same result. Both bar all retroactive legislative rules absent "clear" congressional intent to grant the power. Accordingly, Justice Kennedy's reliance on the clear statement canon over the APA approach suggests that the majority believed Justice Scalia's position was weak and, most importantly for present purposes, that the canon was preferable to the Retail, Wholesale approach. The district court had in fact applied Retail, Wholesale in striking down the rule, clearly identifying that option for the Court. See Bowen v. Georgetown Univ. Hosp., 488 U.S. 204, 205-06 (1988).

The Court's suggestion that there should be "reluctan[ce]" to find authority for retroactivity even where "some substantial justification" is present could be construed as consistent with the incorporation of a non-retroactivity presumption into a weighted balance. See id. at 208-09. At other points, Justice Kennedy's statements regarding the importance of "express language," id., suggest a test more demanding in its application than Retail, Wholesale. See supra text accompanying notes $143,150,186$.

But even if the Chenery II/Retail, Wholesale balance should be tilted against retroactivity and even assuming the Bowen Court wanted to incorporate that approach to some degree, the former is preferable to the Bowen statement of the appropriate methodology. Chenery II and Retail, Wholesale openly acknowledge the factors courts should consider in cases of retroactivity and, in this way, may lead to better, more honest results. At least they may be less likely to mislead than a clear statement canon with its unclear demands. 
of the financial impact of the HHS rule on the hospitals weakened the case for retroactivity even under a balancing approach. ${ }^{197}$

Accordingly, one approach to the Bowen canon is to regard it as mere dictuin used to dispel remaining doubts about its conclusion on the merits. If so, agencies may perhaps safely ignore Bowen's clear stateinent principle in the future. However, it is unlikely that the Court intended to make such an epheineral stateinent regarding statutory construction. The prominent placement of the clear statement canon at the outset of the opinion suggests that the presumption provided the framework for approaching the issues and was not a superfluous afterthought. ${ }^{198}$

2. Use of Administrative and Statutory "Need" as Surrogate for Clear Statement. Justice Keunedy's opinion inight be construed to suggest that the requirement for "express," or at least "clear," statutory authorization may be relaxed in some instances. Although courts are told to be "reluctant" to find authority for retroactivity on the basis of "substantial justification," 199 Justice Kennedy also notes that the canon apphes "as a general matter." 200 However, if the Court permits "mere" need or at least "extreme" need to justify retroactive rulemaking in the absence of an "express" grant, then several dileminas arise. First, a strict notion of delegation, such as that evidenced in Bowen, requires a showing of evidence of congressional intent to grant retroactive rulemaking authority. Moreover, if a reasoned agency justification for retroactivity short of a showing of extreme need is sufficient, then Bowen will have bittle bite despite the Court's apparent intent to hinit retroactive rulemaking. This suggests that Justice Kennedy did not intend to consider mere need to be sufficient.

Second, if the standard is extreme need, ${ }^{201}$ then the problem for the Court (and those attempting to divine its message) becomes squaring that approach with the fact that such a demand generally is not inposed on

197. Upholding retroactivity would have also permitted HHS to escape the consequences of an earlier judicial invalidation of its rulemaking efforts for failure to comply with the APA's procedural mandates. See infra text accompanying notes 316-18.

198. See supra text accompanying note 154 \& infra text accompanying note 213 . The unanimity of Bowen could be explained by what some might consider the temerity of the conduct and positions taken by the HHS prior to and during the litigation of this case. Accordingly, this temporary judicial coalition might evaporate in less egregious instances of agency retroactivity. However, one would generally expect that if Justices other than Justices Kennedy and Scalia did not concur in the general approach, they would have filed separate and limited concurrences.

199. Bowen, 488 U.S. at 208-09.

200. Id.

201. Although the Court dismissed HHS's arguments in terms of "important administrative goals," this rejection could have been based on the persuasive evidence of congressional intent to deny the agency retroactive power in the circumstances presented. 
an agency's assertion of power with regard to matters other than retroactivity. Why is formal retroactivity treated differently than the de facto retroactive impact of formally prospective rules?202 Unless a court assumes what is to be proven-that Congress intended to deny retroactive rulemaking power-no reason exists for the statutory language of a general rulemaking grant, in and of itself, to be deemed insufficient to support an assertion of retroactive rulemaking power.

\section{The Scalia Concurrence: The Relevance of the Administrative Procedure Act}

The majority in Bowen enumerated a new rule of statutory interpretation. In a separate concurrence, however, Justice Scalia attempted to rewrite administrative law in the process of examining the basic statutory embodiunent of its general principles.

Justice Scaha rehed heavily on the order/rule dichotomy in his Bowen concurrence. ${ }^{203}$.In particular, his reasonimg hinged upon the definition of "rule" found in section 551 of the APA:

[T] he whole or a part of an agency statement of general or particular applicability and future effect designed to implement, interpret, or prescribe law or policy or describing the organization, procedure, or practice requirements of an agency and imcludes the approval or prescription for the future of rates, wages, corporate or financial structures or reorganization thereof, prices, facilities, appliances, services or allowances therefor or of valuations, costs, or accounting, or practices bearing on any of the foregoimg. ${ }^{204}$

Focusing on the references to "the future" provided in the APA's definition of a "rule," Justice Scaha concluded that "[t]he only plausible reading of the itahicized phrase [future effect] is that rules have legal consequences only for the future."20s

202. See supra text accompanying notes $22-25$.

203. There is nothing in any of the procedures provided by the APA for administrative agencies that appears to take its shape from the prospective or retrospective impact of the agency decision that results from these processes. The APA classifies agency processes as either rulemaking or adjudication. See 5 U.S.C. § 55I(5)-(7) (1988); B. SchwarTz, Administrative LaW 146 (2d ed. 1984). Whatever is not rulemaking falls within the residual category of adjudication. See 5 U.S.C. $\S 551(6)$-(7) (1988). Rulemaking procedures mentioned in the APA include the "elemental" notice and comment, see id. $\S 553(\mathrm{~b})$-(c), or trial-type procedures, see id. $\S \S 553(\mathrm{c}), 556,557$, depending on whether Congress in auother statute specified that the matter be decided "on the record" after a hearing. For adjudication, the APA outlines procedures for "on the record" hearings. Id. $\S \S 554$, $556,557$.

204. 5 U.S.C. $\$ 551(4)$ (1988) (emphasis added).

205. Bowen v. Georgetown Uuiv. Hosp., 488 U.S. 204, 216 (1988) (Scalia, J., concurriug). The same view was expressed in dicta and without elaboration of its bases in Retail, Wholesale, and Dep't Store Union v. NLRB, 466 F.2d 380, 385 (D.C. Cir. 1972). See also Allen, Thoughts on the Jeopardy of Rules of Long Standing to Procedural Challenge, 33 ADMIN. L. REv. 203, 209 (1981) 
This conclusion is not obvious. The statute does not say "only for the future," but Justice Scaha's gloss added the crucial word. Why? Short of a claim that a statute or a rule (whether defined according to ordinary usage or platonic forms) loses its character as such if it has both prospective and formally retroactive legal effects, Justice Scalia's logical leap appears unsupported. Justice Scalia did cite the Attorney General's Manual in support of his construction. ${ }^{206}$ The Manual expressly equates administrative rulennaking with legislation, ${ }^{207}$ and, like the APA, suggests that a rule is not a rule within the meaning of section 551(4) unless it has future effect. ${ }^{208}$ But the Manual never says that an agency statement loses its status as an APA rule if it has some retroactive legal effect in addition to future effect. ${ }^{209}$

According to Justice Scalia's arguinent, reading the APA definition of "rule" to include agency statenients with both retroactive and prospective effects would eliminate the distinction between "rules" and "orders" (the end product of the adjudicatory process as defined by the APA), 210 and "would thus destroy the entire dichotony upon which the most significant portions of the APA are based."211 The truth of these

(raising but not answering the question presented by the use of the term "future effect" in section 551(4)).

206. Bowen, 488 U.S. at 218-19 (citing ATTORNEY GENERAL'S MANUAL, supra note 152, at 1314).

207. AtToRney General's ManUaI, supra note 152, at 14.

208. Id.

209. See generally B. SCHWARTZ, supra note 203, at 148. Professor Schwartz, like Justice Scalia, focuses on the "future effect" language as important to prevent a collapse of the distinction betwecn rulemaking and adjudication within the meaning of the APA, although Professor Schwartz's concern is created by the APA's definition of "rule" to include statements of "particular" applicability. See also 2 K. DAvIs, supra note $143, \S 7: 23$, at 114 . I agree with Justice Scalia that the statutory references to "future" effect encompass more than the matter of "effective date" of a regulation. See Bowen, 488 U.S. at 217. The Department of Justice appears to have taken the same position. See ATtORNEY General's MANUAL, supra note 152, at 14 ("Rule making is agency action which regulates the future conduct of either groups of persons or a single person . . . ."). Congress must have intended section 551(4) to dcal with a different issue. The discussion in the text and the recommendations that follow proceed on the basis of this assumption regarding the meaning of the APA. But see Schauer, A Brief Note on the Logic of Rules, with Special Reference to Bowen v. Georgetown University Hospital, 42 ADMIN. L. REV. 447 (1990).

Legislative rules have the legal "effect" of statutes because of congressional delegation of power to the agency, while interpretative rules lack such a delegation as their basis, although, on aecount of "deference" to the agency, such rules may judicially be given the "effect of law." See $2 \mathrm{~K}$. DAvis, supra note 143, § 7:09-7:12. The APA refers to interpretative rules, 5 U.S.C. § 553 (1988), rules which the courts routinely trcat as retroactive.

The "rule" at issue in Bowen did not apply at all to future events. Curiously, Scalia made nothing of this fact and ignored the consequences under the APA. See Bowen, 488 U.S. at 216 (Scalia, J., concurring).

210. 5 U.S.C. $\S 551(6)$ (1988).

211. Bowen, 488 U.S. at 216; see also B. ScHWARTZ, supra note 203, at 148 (presenting APA definitions of "rule" and "order"). 
assertions is not self-evident, however. An absolute rule/order distinction simply calmot be inaintained in a formalistic fashion, least of all in the context of the APA. For example, although one might argue that "rules" can be distinguished froin "orders" by their general, as opposed to "particular" effect, ${ }^{212}$ the APA contenplates soine "rules" that have "particular," rather than general, apphicability. ${ }^{213}$ Justice Scalia's formahisin is, therefore, undercut by the APA itself.

Putting aside Justice Scalia's wooden gloss on section 551(4), Scalia also argues that the APA itself operates as a limit on agency discretion to adopt retroactive statements having the force of law. ${ }^{214}$ But how does that square with section $558(\mathrm{~b}),{ }^{215}$ which implicitly indicates that the APA neither expands nor contracts agency substantive legal authority? How can a definitional section, whose only apparent function is to trigger certain procedures, limit agencies' assertion of powers which have their sources outside the APA? Justice Scalia leaves these questions unaddressed. ${ }^{216}$

Moreover, Justice Scaha admits that an agency can adopt retroactive "rules" with "special" congressional authorization. ${ }^{217}$ Do such "rules" fall outside section 551 with the consequence that they are exempt from APA ruleinaking procedures? Section 559 leaves rooin for "additional requireinents imposed by statute" and permits departures from the APA scheme if Congress "expressly" so provides, 218 but legislation that allows the type of retroactive rulennaking that Justice Scalia envisions would presumably not add to APA rulemaking procedures nor seek an exemption from APA coverage. His gloss on section 551(4) suggests that Congress would have to not only expressly provide for retroac-

212. See Administrative Conference of the United States, a Guide to Federal AGENCY RULEMAKING 18 (1983); see also infra note 330.

213. See 5 U.S.C. $\S 551(4)(1988)$.

214. This reading of Justice Scalia's opinion is based upon sentences such as the following: "Although the APA was enacted over 40 years ago, this Court has never directly confronted whether the statute authorizes retroactive rules," Bowen, 488 U.S. at 221-22; "Given the traditional attitude towards retroactive legislation, the regine established by the APA is an entirely reasonable one: Where quasi-legislative action is required, an agency cannot act with retroactive effect without soine special congressional authorization," id. at 224; "The issue is whether it is a permissible form of agency action under the particular structure established by the APA," $i d$. at 225; "despite the limitation of the APA," id. at 224-25. Of course, if the upshot of Justice Scalia's reasoning is not that suggested in the text, it is unclear from his opinion what independent relevance the APA has to the issue in Bowen.

215. See 5 U.S.C. $\$ 558(b)(1988)$.

216. For a theory regarding the effect of the APA on agency discretion (in this case the discretion to make policy otherwise than by APA rulemaking procedures), see Mayton, supra note 33 .

217. Bowen, 488 U.S. at 222-23.

218. 5 U.S.C. $\$ 559$ (1988) ("This subchapter ... do[es] not limit or repeal additional requirements imposed by statute or otherwise recognized by law.... Subsequent statute nay not be held to supersede or modify this subchapter . . . except to the extent that it does so expressly."). 
tive rulemaking but also broaden the APA definition of "rule."219 Justice Scalia has failed to clarify why it is necessary to force this exercise with respect to retroactive rules. 220

In sum, there is nothing in the APA that clearly disqualifies an agency action from being classified as a "rule" under section 551(4) by virtue of its retroactive effect. Even if it did, the sole legal consequence would be that the agency action would fall within the residual definition of "order." But since the APA, for the inost part, prescribes procedures only for formal adjudication-procedures triggered by statutes outside the APA that expressly or inplicitly mandate a hearing "on the rec-

219. Fortunately or unfortunately, neither Congress nor the agencies have used consistent terminology. See, e.g., 15 U.S.C. § 1392(a) (1988) (motor vehicle safety standards established by "order") and $i d$. $\S 1392$ (b) (APA made expressly applicable). See generally B. SCHWARTZ, supra note 203, at 143-45 (discussing terminology and the APA).

If the use of APA terms or cross-references to Section 551 should be deemed to represent legislative adoption of the APA definition of "rule" as a limit on agency substantive authority, then Justice Scalia's reading of Section 551(4), even aside from its direct substantive import, would legally prohibit retroactive rules not expressly authorized by Congress. Since parts of the Medicare Act implicated in Bowen use the term "rule," see, e.g., 42 U.S.C. $\S 405$ (a) (1988), that argument might have been available there. Either Justice Kennedy overlooked this or intentionally avoided this potentially drastic course of action. See also supra note 196.

220. Certainly courts are adept at "deeming"-creating legal equivalence out of the air. A court might "deem" the APA so amended, but that would likely not refleet the discovery of an actual congressional intent to amend and may be inconsistent with seetion 559's requirement of "express" amendment. Justice Scalia's general views regarding the appropriate role of the courts do not suggest he would be an advocate of the broad power "to deem" an amendment to have occurred. See, e.g., Scalia, supra note 187 , at 515 .

Interestingly, he explains Addison as an example of "implicit" statutory authorization for retroactivity, see Bowen, 488 U.S. at 222, despite the language of the opinion which suggests inherent judicial authority on the basis of "need." See supre text accompanying notes 97-98. His reading of Addison may give hope to "partisans" of retroactive rulemaking, but actually his interpretation was intended to undercut the government's argument in favor of the authority for retroactive rules. His suggestion of "implicit" authority may have been a momentary convenience. By overlooking the judicial authority basis in Addison, Justice Scalia casts doubt on his adherence to a reading of Bowen to permit judicially authorized retroactivity in the case of an invalidated agency rule. See infra note 301.

The argument might be made that, to the extent Congress has enacted statutes since 1946 that authorize agencies to adopt legislative "rules" and has thereby adopted the definition of "rule" provided in section 551(4), as glossed by Justice Scalia, agencies operating under those statutes may adopt only prospective regulations. But in that case it is not the APA by its own force that limits agency authority.

Justice Sealia did not look to section 553(d) for support of his interpretation of the APA. That provision generally requires publication of a substantive rule not less than thirty days before its effective date. 5 U.S.C. $\$ 553$ (d) (1988). The legislative history of this section explains its purpose as to "afford persons affected a reasonable time to prepare for the effective date of a rule or rules or to take any other action which the issuance of rules may prompt." Administrative Procedure Act, $\mathrm{S}$. REP. No. 752, 79th Cong., 1st Sess. 15 (1946). See also H. REP. No. 1980, 79th Cong., 1st Sess. 25 (1946). In other words, Congress fashioned the provision to mitigate problems of "surprise." However, as Justice Scalia concedes, a rule that complies with Section 553(d) can purport to have legal effects for the time prior to its effective date. Bowen, 488 U.S. at 217-18. 
ord"-to classify a retroactive action as an "order" would result in few applicable APA procedures. ${ }^{221}$ In other words, the ironic consequence of declaring that a retroactive rule is not a "rule" for APA purposes could be that an agency would become able to issue retroactive rules without the safeguards of APA ruleniaking procedure-a result that would make retroactive ruleniaking easier for agencies to accomplish than other forms of rulenıaking.

\section{The Aftermath of Bowen IN THE Courts}

It is too early to determine the full effect of Bowen on the jurisprudence of retroactivity and the results in litigated cases in the federal courts. ${ }^{222}$ However, recent cases suggest that its influence niay be substantial.

Bowen has ignited renewed interest on the Suprene Court regarding the consistency of its retroactivity caselaw. Moreover, in dealing with retroactivity issues in a variety of contexts, lower courts are now searching nore assiduously than before for congressional intent. Those same courts also are exploring Bowen's inipact in new areas. In short, the problen of defining the appropriate scope for retroactive lawniakingboth legislative and admmistrative-is finally getting the focused attention it deserves but has rarely been given.

221. In the peculiar circumstances of Bowen, it might have been argued that the fact that the "rule" would require repayment of previous reimbursements triggered due process hearing requirements and, under the authority of Wong Yang Sung v. McGrath, 339 U.S. 33 (1950), activated the formal adjudication provisions of the APA. If that argument were unsuccessful, the regulation in Bowen would avoid APA procedures-but not because it had some formal retroactive effect. The APA definition of "rule" is broad enough to encompass statements that have at the same time both prospective and retroactive effect. But if a regulation has solely retroactive legal effects (although it is general in its impact), as did the regulation in Bowen, then it lacks the prospectivity that Section 551(4) seems to specify as a characteristic of agency statements that are to be considered APA "rules." Thus, Bowen exposes a lacuna in the statute that may require elimination. See infra text accompanying notes 223-32.

222. For a recent, path-breaking study casting light on the impact of Supreme Court doctrine on the decisions of the lower courts, see Schuck \& Elliott, To the Chevron Station: An Empirical Study of Federal Administrative Law, 1990 DukE L.J. 984, 1020-43 (noting the initial impact of Chevron on the rate of judicial affirmance of agency action, which effect was, as time went on, eroded for rcasons not entirely clear).

In at lcast two cases after Bowen, lower courts invalidated the retroactive application of HHS regulations. Within weeks of Bowen, a district court, in Minnesota Hospital Association v. Bowen, 603 F. Supp. 780, 786-88 (D. Minn. 1988), ruled that the Secretary of HHS exceeded his authority in applying a 1986 rule for calculating Medicare reimbursements for malpractice premiums to pre-1986 claims for reimbursement. The Sixth Circuit, in Leila Hospital and Health Center v. Bowen, 873 F.2d 132, 132-34 (6th Cir. 1989), remanded a lower court ruling in favor of the agency so that the district court could determine the relief to which the plaintiff was entitled. Leila involved the Bowen wage-index reimbursement rule. 


\section{A. Bowen in the Supreme Court}

More than a year after Bowen, the Supreme Court handed down its decision in Kaiser Aluminum \& Chemical Corp. v. Bonjorno. ${ }^{223}$ Bonjorno involved the retroactive application of that part of the Federal Courts Improvement Act of 1982 that revised statutory provisions concerning post-judgment interest.224 The statute became effective after the initial judgment had been entered in the case but prior to final disposition in the district court. Justice O'Connor's opinion (for five members of the Court) noted the "apparent tension" between the retroactive presumption of Thorpe and Bradley and the rule apphed in Bowen. ${ }^{225}$ Finding clear congressional intent against retroactivity, the O'Connor opimion made no atteinpt to resolve that tension.226

Writing on behalf of the four dissenters, Justice White discovered no such congressional intent and, following Thorpe, would have apphed the new statute. In doing so, Justice White read Thorpe narrowly, suggesting that the retroactivity-favoring canon may apply only to clianges in the law that occur during the pendency of adjudicative proceedings. ${ }^{227}$

While joining the O'Connor opinion in Bonjorno, Justice Scalia wrote a separate concurrence in which he argued at length that the Court should have taken the opportuinity to resolve what he saw as the "irreconcilable contradiction" between the Thorpe/Bradley line of cases and Bowen ${ }^{228}$ in favor of a clear prospectivity-favoring approach. ${ }^{229}$ Among other things, he argued that Thorpe was inconsistent with the overwhelming weight of precedent (both prior to and after the decision in that case), ${ }^{230}$ that logically its approach could not be restricted only to pendimg cases, ${ }^{231}$ and tliat a retroactivity-favoring canon was "contrary to fundamental notions of justice, and thus contrary to realistic assessinent of probable legislative intent."232

Given Justice Scalia's hostility to Thorpe, the apparent willingness of the dissenters to read that case narrowly, ${ }^{233}$ and the plurali-

223. 110 S. Ct. 1570 (1990).

224. Pub. L. No. $97-164,96$ Stat. $25,55-56$ (1982) (amending 28 U.S.C. $\S 1961$ ).

225. Bonjorno, $110 \mathrm{~S}$. Ct. at 1577.

226. See id.

227. Id. at 1591-92 (White, J., dissenting). Justices Brennan, Marshall, and Blackmun joined Justice White's dissent.

228. Id. at 1579 (Scalia, J., concurring).

229. Id.

230. Id. at 1579-86 (citing Bowen v. Georgetown Univ. Hosp., 488 U.S. 204 (1988); United States v. American Sugar Ref. Co., 202 U.S. 563 (1906)).

231. Id. at 1585-86.

232. Id. at 1586 .

233. Id. at 1592 (White, J., dissenting). 
ty's ${ }^{234}$ refusal to resolve the tension between Thorpe and Bowen, Thorpe appears headed for a future in which its applicability is very limited-if it survives at all.

\section{B. Bowen in the Benefit Context}

The Bowen opinion did not address the scenario in which regulated parties or others benefit froin a retroactive rule. As an abstract niatter, the issue of the agency's legal authority would appear to be the same ${ }^{235}$ and, to date, courts have seenied to so treat it.

After Bowen this question reached the court of appeals in Beverly Hospital v. Bowen. ${ }^{236}$ The district court invalidated a regulation adopted by the Health Care Financing Administration (part of HHS), which required hospitals to pay for photocopies of inedical records for the use of peer review organizations. Although the regulation contradicted a statutory provision that such costs "be paid directly by the Secretary to [peer review organizations] on behalf of" the hospitals, the court refused to grant the plaintiffs' request for immediate reimbursement. ${ }^{237}$ Instead, it suggested that such rehef required a rulennaking on reimbursement. On appeal to the D.C. Circnit, plaintiffs argued that the regulatory void could not be filled by a retroactive rule. Noting the Bowen clear statement canon and the failure of the agency to claim statutory authority for adopting a retroactive rule in this instance, the court of appeals nevertheless directed that the district court retain the case "until it is satisfied that, with respect to photocopying costs, the hospitals are accorded the treatinent they would have received had the agency initially regulated" in accordance with the statute. 238 The opaque opinion of the panel suggests that there inight be specific statutory authority for retroactive adjustment in this case and that the agency's failure to claim that authority was

234. Justices Rehnquist, Kennedy, Stevens and O'Connor formed the plurality, with at least Rehnquist, Kennedy, and O'Connor unlikely to give Thorpe a broad reading.

235. The courts have not seemed to recognize a distinction between the retroactive imposition of costs and benefits on parties. For example, in Bennett v. New Jersey, 470 U.S. 632 (1985), see supra text accompanying notes 77-83, retroactive application of the new statute would have benefitted the state, but the Court refused to apply the statute retroactively. While it is true that the United States might have borne the "costs" of retroactivity there, it is equally trne that retroactive cost reimbursement to health care providers would impose "costs" on the United States. Retroactivity almost invariably benefits some and harms otlers. Thus, explicit attention to the balance between costs and benefits is preferable to abstract analysis of legal authority and invocation of presumptious and "canons."

236. 872 F.2d 483 (D.C. Cir. 1989) (per curiam). Ironically, Judge Harry Edwards, who authored the later-affirmed appellate opinion in Bowen, was a member of this panel, which chose to issue an unauthored per curiam opinion.

237. Beverly Hosp. v. Bowen, No. 86-3079-LFO, slip op. at 1 (D.D.C. Oct. 20, 1987) (1987 WL 19217) (quoting 42 U.S.C. $\$ 1395 \mathrm{cc}(\mathrm{a})(2)(\mathrm{f})(1988)$ ).

238. Id. at 484 . 
"nothing more than an agency's convenient litigating position."239 Beverly might also be taken as implying that, even if the agency indeed lacked statutory authority, the district court had "inherent authority" to provide reimbursement. ${ }^{240}$ However, those Supreme Court justices who believe in a restrictive approach to agency authority may take a dim view of such expansive judicial remedial authority. ${ }^{241}$

The D.C. Circuit again confronted retroactivity in the benefit context in a case free from the complications of a previously invalidated agency rule. In General Motors Corp. v. National Highway Traffic Safety Administration, ${ }^{242}$ several autoinobile manufacturers filed petitions for rulemaking with the National Highway Traffic Safety Administration (NHTSA) in order to relax the fuel economy standards for passenger cars manufactured in prior years. NHTSA denied the petitions and concluded that amendments to the standards made after the beginning of the model year would conflict with the statutory scheme. In the wake of Bowen, the agency urged the D.C. Circuit to decide that Bowen barred the retroactive relief requested.

In her unanimous opinion for the court, then-Chief Judge Wald observed,

While Bowen does create a presumption of statutory construction against retroactive rulemaking, it does not establish an absolute prohibition against such rulemaking. Bowen, nevertheless, does send a clear signal that agencies and courts must find congressional authorization for retroactive rulemaking in the particular law they are construing. ${ }^{243}$

Under one interpretation, this passage might be dismissed as simply stating the obvious. The Supreme Court could not outlaw retroactive rulemaking per se without finding it unconstitutional, and Bowen only dealt with statutory interpretation. Judge Wald may, however, have meant that she did not read Bowen's demand for clarity to require express language or incontrovertible proof of congressional intent in order to grant authority to act retroactively.

239. Id. at $485-86$ (quoting Bowen, 488 U.S. at 213).

240. The court does cite Addison with a "cf.," $i d$. at 486, although the reference is to the concurrence of Justice Roberts who did not entirely agree with the majority's approach to the problem of remedy. See supra text accompanying notes 94-100. Writing the opinion for the court in Air Transport Ass'n v. Department of Transportation, 900 F.2d 369 (D.C. Cir. 1990), Judge Edwards first found that the Federal Aviation Administration's rules governing adjudication of administrative civil penalty actions violated the notice and comment requirements of the APA. Then, in "the exercise of our equitable remedial powers," the court permitted the agency "to hold pending actions in abeyance [while it engages in further rulemaking]"-rulemaking which could be applied to the pending actions. Id. at 380-81.

241. See supra text accompanying note 187.

242. 898 F.2d 165 (D.C. Cir. 1990).

243. Id. at 169 . 
Although the scope of Bowen's prohibition of retroactive rulemaking remamed unclear, its application to the benefit context proved unproblematic. Judge Wald did not dismiss Bowen as mapphicable to General Motors Corp. on the basis that the regulated parties sought regulatory rehef or a benefit. Slie noted in passing that NHTSA's relaxation of standards in other contexts had provoked suits by environmental and consumer groups. ${ }^{244}$ The implicit message was that an attempt to limit Bowen to contexts in which "burdens" are being imposed would fail because one person's benefit is another's detriment.

Nevertheless, Judge Wald did not think Bowen "controlled" the disposition of the case. ${ }^{245}$ On the basis that the agency had construed the relevant statute, Judge Wald approaclied the issue of statutory authority under an ordimary Chevron analysis. ${ }^{246}$ Looking first for congressional intent "to bar NHTSA from requiring that amendments to reduce the [fuel economy] standard be made prior to the beginning of the model year"247 and discovering none under Step One of Chevron, ${ }^{248}$ the court then accepted what it found to be a reasonable interpretation by NHTSA. ${ }^{249}$ According to Judge Wald, tlie court did not need "to speculate whether the agency could liave interpreted [the statute], consistently with Bowen, to authorize retroactive rulemaking."250

But Bowen must of necessity be an important and direct aspect of the analysis in this type of case. If Chevron's Step One analysis resulted in a finding of congressional intent to grant NHTSA retroactive rulemaking authority, then the agency's action in this case should have been reversed. If that intent were indeed discovered, then reversal of the agency decision would presumably signify that the agency could grant (where appropriate) the type of retroactive relief requested by General Motors; the NHTSA's reason for not acting on the manufacturer's petitions

244. See id. at 168 n.5.

245. Id. at 169 .

246. In Chevron, USA, Inc. v. NRDC, 467 U.S. 837 (1984), Justice Stevens noted,

When a court reviews an agency's construction of the statute which it administers, it is confronted with two questions. First, always, is the question whether Congress has directly spoken to the precise question at issue. If the intent of Congress is clear, that is the end of the matter; for the court, as well as the agency, must give effect to the unambiguously expressed intent of Congress [Step One]. If, however, the court determines Congress has not directly addressed the precise question at issue, the court does not simply impose its own construction on the statute, as would be necessary in the absence of an administrative interpretation. Rather, if the statute is silent or ambiguous with respect to the specific issue, the question for the court is whether the agency's answer is based on a permissible construction of the statute [Step Two].

Id. at 842-43 (footnotes omitted).

247. General Motors, 898 F.2d at 170.

248. Id. at 170-72.

249. Id. at 172-77.

250. Id. at 169 (citing Chevron, 467 U.S. at 837). 
would have been improper. Yet Bowen teaches that the authority to engage in retroactive rulemaking must be clearly given. This suggests that, whether or not an agency has asserted retroactive rulemaking power, Step One of a Chevron analysis must search for Bowen-required "clear" evidence of congressional intent to grant authority to engage in retroactive rulemaking. If such evidence is not found, retroactive rulemaking must, as a matter of law, fail.

Although the court did not decide whether NHTSA could have asserted retroactive power, its analysis suggested that a claim of retroactive authority may have been insupportable under a Bowen analysis. The court did not find clear congressional language relating to the inatter of retroactive authority, but rather upheld the agency's action because its reading of the statute was "reasonable." Nevertheless, had the agency asserted retroactive rulemaking power and sunmoned a persuasive argument in terms of statutory language, purposes, and context, the court may have accorded the agency views controlling weight, at least to the extent that the court beheved the existence of Bowen-required clarity was a close question. ${ }^{251}$

\section{Adjudicatory Retroactivity}

Adjudicatory retroactivity traditionally has been accepted subject to the balancing tests of Chenery II and Retail, Wholesale. The Bowen canon's effect on these decisions is not clear. ${ }^{252}$ Because such a thin line separates rulemaking from adjudication, ${ }^{253}$ the effect of Bowen may stretch beyond the legislative rulemaking arena.

One lower court has addressed adjudicatory retroactivity in the post-Bowen world. In General American Transportation Corp. v. ICC, the D.C. Circuit rejected the extension of Bowen to the adjudications at issue before the court. 254 . General American grew out of a complaint filed against railroads for their assessment of various charges under new tariffs. The ICC sought industry comment on the issues framed by the par-

251. See supra note 174. It should be noted that Judge Wald conducted her Cherron Step One analysis without giving any apparent weight or consideration to NHTSA's views. Howcver, an agency interpretation pinned, in part, on congressional goals and administrative needs would not tip the balance until, under Cherron Step One, the court first independently examined congressional intent. Cf. General Motors, 898 F.2d at 172 ("Only in those cases where the agency has stopped at text and history without weaving into the calculus policy and administrative concerns might a court which finds the textual or historical analysis nondeterminative feel compelled to remand the case to the agency for an exercise of its discretion [under Chevron Step Two].").

252. Bowen v. Georgetown Univ. Hosp., 488 U.S. 204, 216-25 (1988) (Scalia, J., concurring). Justice Scalia accepted adjudicatory retroactivity in his view of the APA.

253. See supra text accompanying notes 101-03.

254. 883 F.2d 1029 (D.C. Cir. 1989). In General American, the court denied the petition for rehearing. For the earlier decision, see 872 F.2d I048 (D.C. Cir. 1989). 
ties and ultimately reversed a forty-year-old policy concerning empty repair moves for railroad cars. It was argued that the comment procedures turned the proceeding into a rulemaking and thus retroactivity was impermissible. Noting that "[i]t is unproductive, in most circumstances, to atteinpt to 'classify a given proceeding as eitlier adjudicatory or rulemaking," "255 Judge Silberman observed in General American that "the cliaracterization . . . is important, for it bears directly on the propriety of retroactive application of the new governing primciple."256 Judge Silberman found tliat, having "begun as an adjudication by certain of the petitioners with the filing of a complaint against the railroads ... [the proceeding] retained its fundamental adjudicatory character throughout"257-despite the addition of comment procedures characteristic of APA rulemaking.

\section{Statutory Construction}

Bowen appears to have breathed new life into the Greene canon's method of interpreting statutes and regulations. In a series of cases that involved statutory amendments enacted during the pendency of litigation (a situation in which the retroactivity-favoring Thorpe canon would appear to be on point), the amendments were not applied retroactively, im part because of the lack of clear congressional intent. ${ }^{258}$ Furtherniore, courts, relying on Bowen, refused eitler to apply legislative rules retroactively 259 or to allow a retroactive effect of an interpretative

255. General American, 883 F.2d at $1030 \mathrm{n} .2$ (quoting City of Chicago v. FPC, 458 F.2d 731, 739 (D.C. Cir. 1971), cert. denied, 405 U.S. 1074 (1972)).

256. Id. Judge Silberman cited to Bowen in this context.

257. Id. at 1030.

258. See, e.g., ALPO Petfoods, Inc. v. Ralston Purina, 913 F.2d 958 (D.C. Cir. 1990) (section 43(a) of the Lanham Act not to be applied retroactively); DeVargas v. Mason and Hansen-Silas Mason Co., Inc., 911 F.2d 1377 (10th Cir. 1990) (involving the Civil Rights Restoration Act of 1987 and discussing the Supreme Court's retroactivity caselaw in light of Bonjorno); Ulmet v. United States, $17 \mathrm{Cl}$. Ct. 679, 696 (1989) (a detailed opinion by Judge Horn surveying the retroactivity precedents, discussed supra text accompanying notes 52-92, and finding manifest injustice, noting the lack of clear congressional intent in favor of retroactivity); Wilson v. United States, $16 \mathrm{Cl}$. Ct. 765,768 (1989) ("It is concluded that, if Congress had intended that the 1987 language be applied to render officers on training tours of duty prior to its enactinent meligible for sanctuary, this would have been expressly spelled out in the legislation.").

259. See, e.g., Storey v. Shearson-American Express, 928 F.2d 159 (5th Cir. 1991) (regulations of Commodities Futures Trading Conmission regarding arbitration agreennents); Sierra Medical Center v. Sullivan, 902 F.2d 388, 392 (5th Cir. 1990) (HHS "new provider" rule); Criger v. Becton, 902 F.2d 1348, 1354-55 (8th Cir. 1990) (FEMA flood insurance policy rule); Gubisch v. Brady, 49 Fair Empl. Prac. Cas. (BNA) 1063, 1069 (D.D.C. 1989) (holding that the EEOC had no authority to apply the legislative rule at issue retroactively, relying in part on Justice Scalia's interpretation of the APA in Bowen); In re Perkins, 106 Bankr. 863, 86465 (E.D. Pa. 1989) (refusing to construe a Federal Reserve Board rule as retroactive). 
rule. ${ }^{260}$ Bowen's effects are now with us. A crucial concern is its effects on the day-to-day operations of administrative agencies.

\section{SURVEY RESULTS AND RECOMMENDATIONS}

Justice Scalia, noting that the government in Bowen cited only two cases that sustamed retroactive regulations since the 1946 enactment of the APA, concluded that such rules "are evidently not a device indispensable to efficient government." 261 The meaning of this statement is not entirely pellucid.262 But, if he is assuming that retroactive legislative rules are almost as scarce as the dodo bird and that to deny agencies the power to adopt them will not interfere with their functions, then the caselaw in the lower courts discussed above suggests that Justice Scalia is wrong, ${ }^{263}$ as does other available empirical evidence.

\section{A. Survey of Federal Agencies}

1. The Prevalence of Retroactive Regulations. The survey of federal agencies conducted in connection with this Article ${ }^{264}$ confirms the considerable presence of retroactive rulemaking in federal administrative activities. The survey and cases suggest that each of the following agencies has, at one time or another, adopted a retroactive legislative rule:

260. See Lehman v. Bumley, 866 F.2d 33, 37-38 (2d Cir. 1989) (refusing to give retroactive effect to the Secretary of Transportation's interpretation of the Recreational Boating Safety Act).

261. Bowen v. Georgetown Univ. Hosp. 488 U.S. 204, 224 (1988) (Scalia, J., concurring).

262. Is he suggesting, for example, that while there have been other cases involving retroactive rules, most of the rules have not been "sustained" and yet the business of government has gone on?

263. See supra notes $235-60$ and accoinpanying text.

264. See supra text accompanying note 21 . The questionnaire requested narrative responses to the following questions:

1. Since 1980, has your agency at any time adopted a legislative rule which, by its terms, was formally retroactive in its legal effect?

2. If the answer to Question 1 is in the negative, please skip to question 8. If the answer to Question 1 is in the affirmative, please supply citations (FEDERAL REGISTER or CODE OF FEDERAL REGULATIONS) to the retroactive rules adopted by your agency since 1980 . 3. What rationales (or types of rationales) have been relied upon in justification for the retroactivity (e.g. express congressional mandate that the rule be retroactive)?

4. For which of the rules having retroactive effect was there a statute expressly or otherwise clearly granting the agency the power to make the rules retroactive? Please cite the relevant statutory provision.

5. In adopting retroactive rules, were the preadoption procedures (if any) structured in particular ways on account of the retroactive effect of the rules? If so, how were the procedures affected?

6. Regarding the content of retroactive rules, were waiver provisions (based on unusual hardship or other factors) or other features suggested in particular by the retroactivity of the rules? If so, please describe those features suggested by the retroactive nature of the rules.

7. Was the legality of retroactivity of any rule issued by your agency since 1980 challenged by a suit in federal court? With what result? Please give citations to opinions if available.

8. In your opinion, are there any particular issues with respect to the retroactivity of legislative rules which the Cominittee should focus on? If so, what are these? 
The Departments of HHS (including the Food and Drug, ${ }^{265}$ Social Security, ${ }^{266}$ and Health Care Financing Administrations ${ }^{267}$ ), Housing and Urban Development, ${ }^{268}$ Interior (including the Bureaus of Land Management ${ }^{269}$ and Indian Affairs ${ }^{270}$ ), Labor $^{271}$ (including the Occupational Safety and Health Administration ${ }^{272}$ ), and Energy, ${ }^{273}$ along with the Equal Employment Opportunity Commission, ${ }^{274}$ the Office of Personnel Management, ${ }^{275}$ the Federal Deposit Insurance Corporation, ${ }^{276}$ the General Services Administration, ${ }^{277}$ the Internal Revenue Service, ${ }^{278}$ the

265. See, e.g., 47 Fed. Reg. 50,442 (1982) (tamper resistant packaging rule applicable to products on store shelves regardless of date of manufacture); Certified Color Indus. Comm. v. Secretary of HEW, 283 F.2d 622, 628 (2d Cir. 1960) (revocation of color certification of previously manufactured batches of product).

266. See, e.g., 48 Fed. Reg. 40,883 (1983) (disposal of resources for less than fair market value); 47 Fed. Reg. 55,212 (1982) (burial spaces and certain funds set aside for burial expenses); 46 Fed. Reg. 45,756 (1981) (payment for medical evidence of record); 46 Fed. Reg. 4869 (1981) (determining disability and blindness).

267. See, e.g., supra text accompanying notes 118-22.

268. Letter from Frank Keating, General Counsel, Department of Housing and Urban Development to author (Sept. 5, 1989) (on file with author). Some HUD rules are made retroactive to a date after their publication but before their date of announced effectiveness. In addition, Fair Market Rent Schedules for new construction and rehabilitation subsidies may be made retroactive to the effective statutory date for their establishment when there is delay in their adoption.

269. See 52 Fed. Reg. 26,982 (1987) ("defining more precisely when bidders [on timber] are not qualified").

270. See 25 C.F.R. $\S 125.4$ (1990) (removal of sexual bias from criteria for determining eligibility for Sioux benefits).

271. 20 C.F.R. $\$ 725.496-497$ (1983) (liability for black lung benefits shifted from coal mine operators to Black Lung Disability Trust Fund).

272. See Chamber of Commerce v. OSHA, 636 F.2d 464, 467 (D.C. Cir. 1980) ("walkaround" time pay rule made retroactive by the Assistant Secretary of OSHA).

273. See, e.g., Mobil Oil Corp. v. Department of Energy, 678 F.2d 1083, 1083 (Temp. Emerg. Ct. App. 1982) (mandatory petroleum price regulations). See generally Note, Retroactivity and Pricing Regulations, 29 BAYLOR L. REV. 1033, 1034 (1977) (discussing retroactivity of price controls under the Federal Energy Administration of 1974).

274. Gubisch v. Brady, 49 Fair Empl. Prac. Cas. (BNA) 1063, 1063 (D.D.C. 1989) (regulation regarding reopening of cases).

275. See, e.g., Retirement-Credit for Service, 53 Fed. Reg. 42,933 (1988) (codified at 5 C.F.R. $\$ \$ 831.301-.309,842.301-309$ (1990)) (providing qualified employees with an opportunity to earn retirement credit for certain service performed under a personal service contract with a federal agency). The Office of Personnel Management's (OPM) response to the questionnaire lists over 40 rules applicable to entitlements issued since 1980 which have been made formally retroactive. Based on the survey results, OPM is one of the most frequent users of retroactive rules.

276. Questionnaire response from Z. Scott Birdwell, Legal Division, FDIC (June 27, 1989) ("[S]ome rules have minor provisions that permit some retroactivity where the effect will benefit the public.").

277. Letter from J. Jett McCormick, Associate General Counsel, General Law Division, General Services Administration to author (Aug. 8, 1989) ("To the extent any of our regulations have had retroactive effect, they have been based on statutory authorization but, again, this situation arises very infrequently.").

278. See, e.g., Anderson, Clayton \& Co. v. United States, 562 F.2d 972, 974 (5th Cir. 1977) (calculating foreign tax credit), cert. denied, 436 U.S. 944 (1978). See generally Note, The Retroac- 
Federal Communications Commission, ${ }^{279}$ the Federal Reserve Board, ${ }^{280}$ the Immigration and Naturalization Service, ${ }^{281}$ the Pension Benefit Guarantee Corporation, ${ }^{282}$ the Securities and Exchange Commission, ${ }^{283}$ and the Veterans Administration. ${ }^{284}$ The survey gathered data relating to the period since 1980, but given discrepancies between questionnaire responses and reported cases and the lack of easy methods for agencies to identify all instances of retroactive rules, the survey no doubt understates the extent of use of retroactive legislative rules. In many, although not all, instances the retroactive impact was clear on the face of the regulations (rather than the result of agency "interpretation"). ${ }^{285}$

2. Secondary Retroactivity. One finding that resulted from the survey suggests that some agencies view Bowen as limited to instances of

tivity of Treasury Regulations: Paths to Finding Abuse of Discretion, 7 VA. TAX REV. 509, 509 (1988) (discussing the rebuttable presumption of retroactivity on "any ruling or regulation" promulgated by the Internal Revenue Service).

279. 98 F.C.C.2d 175 (1984) (cellular lottery rule); 53 Rad. Reg. 2d (P \& F) 681 (1983), on reconsideration, 56 Rad. Reg. 2d (P \& F) 835 (1984) (eliminating certain policies used to challenge award of new radio and television license applications).

280. Home Mortgage Disclosure, Revisions to Regulation C, 53 Fed. Reg. 31,683 (1988) (codified at 12 C.F.R. $\S 203$ (1990)) (reporting requirements for mortgage banking subsidiaries of bank and savings and loan holding companies).

281. See supra text accompanying notes 123-25; see also Maceren v. District Director, INS, 509 F.2d 934, 935 (9th Cir. 1975) (one-year period of validity of labor certification).

282. Pension Benefit Guar. Corp., 29 C.F.R. pts. 2643, 2644, 2647 at 723-30, 732-39 (1990) (multi-employer pension plans retroactive though statute and regulations protected "reasonable" actions taken prior to adoption of regulations).

283. See, e.g., Blau v. Hodgkinson, 100 F. Supp. 361, 373-74 (S.D.N.Y. 1951) (accepting retroactive application of the Securities and Exchange Commission's Rule X-16B-6).

284. See American Fed'n of Gov't Employees v. Nimmo, 536 F. Supp. 707, 717 (E.D. Va. 1982) (upholding reimbursement of costs of nonservice-connected medical care furnished to ineligible veterans), aff'd on other grounds and vacated in part, 711 F.2d 28 (4th Cir. 1983).

In addition, the NHTSA denied petitions for retroactive rulemaking when the petitions sought retroactive reduction of passenger car fuel economy standards. See Passenger Auto. Average Fuel Economy Standards, 53 Fed. Reg. 15,241 (1988) (codified at 49 C.F.R. § 531 (1990)); Fuel Economy Standards, 53 Fed. Reg. 39,115 (1988) (codified at 49 C.F.R. § 531-5 (1990)). The NHTSA based the denials on the lack of statutory authority for retroactivity. As discussed supra text accompanying notes 242-52, the D.C. Circuit recently upheld those denials.

285. See Lynch v. Lyng, 872 F.2d 718, 723 (6th Cir. 1989) (indicating that Department of Agriculture had adopted retroactive rules). The Internal Revenue Service may be a special case, because by statute its rules are presumed retroactive unless the Secretary of the Treasury otherwise provides. See 26 U.S.C. $\S 7805(b)$ (1988). 
primary retroactivity. ${ }^{286}$ Cases that involve claims of improper retroactive effect fall into two principal categories and several subcategories:287 1. Imposition of new legal standards with regard to past transactions or occurrences in the context of determining:

a. the legal consequences of those past transactions or occurrences for the period up to the effective date of the new statute or agency rule ("primary retroactivity"); and

b. the legal consequences of those past transactions or occurrences for the period beyond the effective date of the new statute or rule. Justice Scalia characterized this variety of retroactivity as "secondary retroactivity."288

2. Imposition of new legal standards for transactions or occurrences after the effective date of the statute or rule for the purpose of determining legal consequences for the future (also included within Justice Scalia's notion of "secondary retroactivity"). ${ }^{289}$

Since people may find that case 1(b) is as objectionable as case 1(a), and because future conduct generally has its roots in the past, it is evident that these situations present variations on the same theme: The need to provide appropriate protection against "undue" surprise and to support "reasonable" reliance interests.

Nothing in Justice Kennedy's opinion suggests that Bowen is limited to cases of purely retroactive legislative rules-as opposed to those with both retroactive and prospective effects. Several agencies, however, view the approach articulated by Justice Kennedy as perhaps inapplicable to instances of secondary retroactivity. Justice Scalia's concurrence prompted this belief by suggesting that the APA does not limit agency authority to issue rules that do not alter the "past legal consequences of past actions." 290 At least one agency behieves (with some uncertainty) that applying new requirements to existing licenses and pending license applications may be an instance of "secondary retroactivity." The ICC suggested that its action in American Trucking ${ }^{291}$ illustrated an instance

286. The distinction between primary and secondary retroactivity derives from McNulty, supra note 24, at 58-60. Those statutes or regulations that change the legal consequences of past events are classed as primary retroactivity. If only the legal consequences of acts subsequent to the new statute or regulation are affected, then the rule is classed as secondary retroactivity. See infra text accompany notes $287-89$.

287. See supra text accompanying notes 22-24.

288. See Bowen v. Georgetown Univ. Hosp., 488 U.S. 204, 219 (1988) (Scalia, J., concurring); McNulty, supra note 24, at 59 (giving as an example of secondary retroactivity "a statute declaring pre-existing obligations unenforceable in the future").

289. Bowen, 488 U.S. at $219-20$ (Scalia, J., concurring) (giving, as an example, taxation of future income of a trust whose income was previously deemed non-taxable).

290. Id. at 219.

291. 467 U.S. 354 (1984); see supra text accompanying notes 101-09. 
of "secondary retroactivity," 292 although it is difficult to distinguish Bowen and American Trucking on this basis. ${ }^{293}$ Yet another agency was unsure whether Bowen was inapplicable to cases of "secondary retroactivity."294

Future hitigation will focus on the applicability of the clear statement canon to cases of "secondary retroactivity." If the canon is found inapplicable, litigation will focus on the classification of types of retroactivity. ${ }^{295}$ In the process, courts will be hard-pressed to invent principled distinctions between types of retroactivity. 296

3. The Benefit Context. Many of the retroactive rules mentioned by survey respondents involved rules that conferred benefits. Since Bowen involved imposition of a legal detriment, the Court might elect to permit retroactive rules absent clear congressional authorization if an agency were coming to someone's aid. After all, Justice Kennedy said that the clear stateinent canon was applicable "as a general matter,"297 and he cited a case decrying the "harsh" nature of some retroactive actions. ${ }^{298}$

None of the survey respondents suggested that they saw this linitation in Bowen, ${ }^{299}$ but the questionnaire did not expressly raise the issue. In one case, the apparent beneficiaries of a rule, the agency, and the court appear to have accepted the applicability of the clear statement canon in the benefit context. ${ }^{300}$ Whether a benefit/burden distinction can be ap-

292. Questionnaire response from Craig M. Keats, Deputy Associate General Counsel, ICC (June 15, 1989) (on file with author).

293. See supra text accompanying note 189.

294. Questionnaire response from Z. Scott Birdwell, Legal Division, Federal Deposit Insurance Corp. (June 27, 1989) (on file with author).

295. See supra note 285.

296. Taking its cue from the Supreme Court in cases such as United States v. Storer Broadcasting Co., 351 U.S. 192 (1956), the lower courts have in the past upheld application of new legislative rules to existing licenses and applieations for licenses without focusing on the issue of retroactivity. See, eg., American Airlines, Inc. v. Civil Aeronautics Bd., 359 F.2d 624, $630-33$ (D.C. Cir.) (en banc), cert. denied, 385 U.S. 843 (1966) (Civil Aeronautics Board regulation valid without complete adjudicatory hearing).

297. See Bowen, 488 U.S. at 208.

298. Id. (citing Brimstone R.R. \& Canal Co. v. United States, 276 U.S. 104, 122 (1928)).

299. In Lynch v. Lyng, 872 F.2d 718, 723 (6th Cir. 1989), the court upheld a claim for food stamp benefits retroactive to the effective date of the Food Security Act of 1985, 7 U.S.C. $\S 2012$ (r) (1988), indicating that the Department of Agriculture's regulations should have so provided. The court did not, however, cite Bowen.

300. Beverly Hosp. v. Bowen, 872 F.2d 483 (D.C. Cir. 1989); see supra text accompanying notes 236-41. They doubtless realized that in most instances of governmental regulation and entitlements, someone's benefit becomes another's direct or indirect burden. For example, relaxing air pollution standards retroactively may not provoke court challenges by polluters, but such an act still harms environmental groups and those living in the affected areas. 
plied to limit the scope of Bowen is doubtful, and the D.C. Circuit's most recent treatment of Bowen in the benefits context, General Motors Corp. v. NHTSA, confirms this conclusion. ${ }^{301}$

\section{B. Side Effects of Bowen and Recommendations}

The survey results and lower court opinions disclose that justifications for retroactivity have varied froin case to case and froin agency to agency; these justifications include argunients that the effective date of legislation ${ }^{302}$ or the creation of statutory entitlements to benefits ${ }^{303}$ warrant allowing a regulation to relate back in tine. Agencies might rely on these justifications, as well as congressional time tables for action to identify "clear" statutory authority for retroactivity. ${ }^{304}$ If such argunients are successful-a doubtful proposition given Bowen's enphasis on the need for express enabling language ${ }^{305}$ - then the impact of Bowen would be reduced. Meanwhile, however, lawyers in and out of government will have to judge for theniselves whether a particular provision is clear enough. The uncertainty left by Bowen regarding the standard of re-

301. 898 F.2d 165 (D.C. Cir. 1990); see supra text accompanying notes 242-52; see also Sierra Medical Center v. Sullivan, 902 F.2d 388, 392-93 (5th Cir. 1990) (court finds nothing in an amended Medicare regulation or the Federal Register Notice even remotely supporting curative retroactive rulemaking and finds retroactive application of the regulation beyond the scope of the Department of Health and Human Service's power); Criger v. Becton, 902 F.2d 1348, 1353-54 (8th Cir. 1990) (relying on Bowen, the court refused to apply the Bradley analysis absent a clear statement from Congress that this power was intended to be conveyed).

If Justice Scalia's APA arguments were to gain acceptance, such a distinction would become legally irrelevant and in the process curative retroactive rulemaking used to protect parties who relied on a rule held invalid would be barred.

In those cases where an agency rule is invalidated on substantive or even procedural grounds, it might be argued that Bowen does not prevent the exercise of the court's own remedial powers to order retroactive relief. Addison v. Holly Hill Fruit Co., 322 U.S. 607 (1944), might be relied on here. See supra text accompanying notes 239-41. It does appear somewhat anomalous, however, to suggest that a court can achieve a result of this kind that the agency on its own cannot. This anomaly might pose particular difficulties for the more conservative members of the Court. See supra text accompanying note 241 .

302. See, e.g., Letter from Darrel J. Grinstcad, Acting Associate General Counsel, Hcalth Care Financing Division, Office of the General Counsel, Department of Health and Human Services, to author (July 5, 1989); Letter (with questionnaire attached) from Donald A. Gonya, Chief Counsel for Social Security, Office of the General Counsel, Department of Health and Human Services to Ernest Gellhoru (June 28, 1989).

303. Letter (with questionnaire attached) from James S. Green, Acting General Counsel, Office of Personnel Management, to author (June 28, 1989). Such a position might be supported by reference to Justice Scalia's concurrence in Bowen v. Georgetown Univ. Hosp., 488 U.S. 204, 224-25 (1988) (referring to instances where a statute requires a rule to be in effect on a particular date).

304. See Lynch v. Lyng, 872 F.2d 718, 722 (6th Cir. 1989).

305. Bowen, 488 U.S. at 208-15. But see supra text accompanying note 186. Justice Scalia would permit retroactive regulations even if the power were only "implicit." See Bowen, 488 U.S. at 223-24 (Scalia, J., concurring). 
quired clarity, as well as the sphere of its application, will provoke litigation and may deter appropriate agency rulemaking.

Another possible side-effect of Bowen is increased agency reliance on the adjudicatory process to develop policy. ${ }^{306}$ Adjudicative retroactivity would be judged under the relatively forgiving standards of Chenery II and Retail, Wholesale. ${ }^{307}$ This, along with other developments over the last decade-which mclude imcreased statutory procedural regulation and presidential supervision of rulemaking - may act to encourage a tendency toward the adjudicatory mode. ${ }^{308}$

Prior to joining the federal judiciary, Justice Scalia viewed a move toward the adjudicatory mode with favor. ${ }^{309}$ During the last quarter of a century, however, courts ${ }^{310}$ and commentators ${ }^{311}$ have encouraged the opposite approach to administrative policymaking. This support for rulemaking is partly a response to an objection to the retroactive effect of adjudicatory proceedings. But there are other advantages of APA rulemaking, including opportunities for public participation and the avoidance of singling out one party at a time. Given the relative infrequency of retroactive rulemaking and the advantages of the rulemaking process, it is unlikely that Bowen, by itself, will influence the choice between rulemaking and adjudication.

In the light of Bowen's effect on the validity of retroactive rulemaking-rulemaking that may be justified under a balancing approach-the Supreme Court should reject both the clear statement approach and Justice Scaha's notion of the independent significance of the APA for agency authority. Rather, the Court should submit retroactivity problems to a case-by-case analysis im the fashion of Chenery II and Retail, Wholesale. Courts should rely on this approach unless Congress intended to deny an agency the power to adopt retroactive legislative rules. ${ }^{312}$ This approach guarantees that the same generic problem will not be treated differently

306. Justice Scalia contemplated this side-effect. See Bowen, 488 U.S. at 223-24 (Scalia, J., concurring).

307. See supra text accompanying notes 31-38.

308. See Scalia, supra note 13 , at 25 .

309. Id. at 26.

310. See, e.g., American Airlines, Inc. v. Civil Aeronautics Bd., 359 F.2d 624 (D.C. Cir.) (en banc) (favoring rulemaking over adjudication when the formalities of adjudication are inappropriate), cert. denied, 385 U.S. 843 (1966).

311. See, e.g., Bonfield, supra note 32 , at $168-79$ (discussing why state agencies should prefer lawmaking by rule).

312. The exception can be analyzed under Step One of Chevron. Of course, if Congress clearly authorizes an agency to adopt retroactive rules, its intent must govern unless the authorization or its specific application is arbitrary, capricious, or contrary to constitutional restrictions. These inquiries similarly depend on the Chenery $I I$-type balance. 
based on abstract distinctions between rulemaking and adjudication, ${ }^{313}$ formal and secondary retroactivity, or legislative and interpretative rules. The ultimate question on judicial review will in all cases be whether the rule is "arbitrary and capricious" based on its impact and other relevant factors. ${ }^{314}$ An agency that adopts or proposes to adopt a retroactive legislative rule should-to the extent practicable-present its justification for retroactivity clearly. The explanation should appear in the Federal Register preamble to any proposed or adopted retroactive legislative rule. ${ }^{315}$ In judicial proceedings in which the affected party contends the retroactivity at issue is "arbitrary or capricious," the burden of justifying the retroactivity should rest with the agency.

1. A World Without Bowen. Several scenarios may result if Bowen is ultimately repudiated. First, in a Bowen-like situation, when an agency adopts a retroactive rule to replace a similar rule that was invalidated on substantive or procedural grounds, ${ }^{316}$ courts should consider, among other things, the degree of similarity between the new and old rule. If the new rule is essentially identical to the old, then the court must evaluate the extent to which permitted retroactivity may weaken agency incentives to comply with the APA and to give a "hard look" at the substantive issues. ${ }^{317}$ Accordingly, it may be appropriate to ask the agency to produce a particularly persuasive showing of need for retroactivity in these cases. However, in situations in which the replacement rule differs in important respects from the original, there may be less reason for this heightened showing because of evidence that the agency has reevaluated the inerits. The same inay be true if substantive or procedural mvalidity of the first rule was a close call. The first part of the

313. See supra text accompanying notes 102-03, 276-82.

314. See 5 U.S.C. $\S 706(2)(A)(1988)$. Chevron arguably makes the reasonableness standard applicable to "interpretative" rules.

315. Agencies are required to publish "substantive rules of general applicability" in the Federal Register. 5 U.S.C. $\S 552(a)(1)(D)$ (1988). Explanatory preambles of proposed and final rules are required by the APA, 5 U.S.C. $\S 553$ (b)-(c), and regulations of the Administrative Committee of the Federal Register, 1 C.F.R. $\$ 18.12$ (1990). The suggested justification for retroactive application may already be required. See Exec. Order 12,630, § 5(b), 53 Fed. Reg. 8859 (1988), 3 C.F.R. 554 (1990), reprinted in 5 U.S.C. $\$ 601$ (1988).

316. Justice Kennedy rejected the "curative" theory, at least in the context presented in Bowen. See 488 U.S. 204, 215 (1988).

317. Justice Scalia's concurrence in Bowen raises this issue. See id. at 224-25. The invalidation of the initial rule may force the agency to again confront the substantive merits and comply with the APA's rulemaking procedures, but the first effort at rulemaking may predetermine the result of the second. 
reformulated Retail, Wholesale test found in the Mason General Hospital $^{318}$ embodies this approach.

In a second type of situation, the existence of a congressionally mandated deadline may be an important factor in determining the validity of a retroactive legislative rule. Over the last quarter of a century, Congress has developed a certain fondness for statutory deadlines, ${ }^{319}$ but agencies have often experienced great difficulty in meeting them. ${ }^{320}$ Failure to comply with deadlines often results only in heated committee hearings and time extensions. As deadlines are missed, moreover, intervening circumstances may make retroactivity less defensible. The mere existence of a legislative deadline should not invariably be the determining factor with regard to the permissibility of retroactivity.

Agencies responding to the survey suggested that when Congress makes a statute effective on a particular date, it is assumed that implementimg regulations adopted subsequently can or must be retroactive to that effective date. Yet a statute's effective date and the date on which the created rights and duties attach may be different. ${ }^{321}$ Whether or not the Supreme Court preserves Bowen, the ambiguous implications of statutory "effective dates" for the retroactivity of implementing regulations will prompt confusion and litigation. It is unclear whether such provisions constitute clear evidence of congressional intent on the retroactivity issue. The impact of such provisions on Chenery II balancing also remains unclear. Ideally, Congress should detail the intended relationship of statutory effectiveness provisions to retroactivity of agency rules.

2. A Return to Basics: Congressional and Agency Draftsmanship. This returns us to the basic problem created by Bowen. A marked change in congressional focus and draftsmanship in response to Bowen is unlikely for a variety of reasons, including the crush of legislative duties. Moreover, for two reasons such a change is undesirable. First, Congress

318. 809 F.2d 1220 (6th Cir. 1987); see supra text accompanying note 134. In some cases, in which the court invalidates a rule, it might attempt to stay the effectiveness of the rule pending agency proceedings to correct the defect. Yet when a great deal of time elapses between the remand and final agency action, it still may be unfair to allow attribution of retroactive effect to the subsequently adopted rule because of intervening circumstances beyond the control of the regulated parties. In Bowen, this approach, at least under a balancing analysis, might have avoided the problems presented in that HHS would not have reimbursed the providers.

319. See generally Tomlinson, Report on the Experience of Various Agencies with Statutory Time Limits Applicable to Licensing or Clearance Functions and to Rulemaking, 1978 ADMINISTRATIVE CONFERENCE OF THE UNITED STATES RECOMMENDATIONS AND REPORTS 119 (analyzing the experience of nine agencies subject to statutory time limits and discussing the advantages and disadvantages thereof).

320. Id.

321. See supra note 220. 
is not in the best position to judge ex ante the desirability of retroactivity with regard to a specific implementing regulation-the very insight that is crucial to finely crafted statutory provisions. Second, if Bowen produces legislative boiler-plate provisions on retroactivity, these blanket grants of authority to niake retroactive rules will represent only a imininial effort by Congress to weigh the pros and cons of retroactivity. If boiler-plate language results, then agencies and courts will have to balance relevant considerations to determine the permissibility of retroactivity in particular cases. Under this result, Bowen's impact on retroactivity will evaporate. However, there renains the danger that courts, in light of the congressional language, will fail to scrutimize retroactive rules with sufficient care.

3. Recommendations. The survey of cases and agencies suggests several recommendations to alleviate the probleins of retroactivity. First, agencies might incorporate waivers and/or exceptions in retroactive rules in order to respond to probleins of unusual hardship or rehance. At least one reported case suggested that these provisions can imitigate potential constitutional or other problems with a retroactive rule. ${ }^{322}$ Of course, difficulties with adıministering waiver and exceptions provisions should be taken into account. Second, pre-proposal notice in the Federal Register or discussions with those who may be adversely affected nuay in some instances alleviate problenis of surprise and reliance costs froni a retroactive rule. Reactions to the notice nuay force the agency to decide against proposing a retroactive rule or to revise certain provisions.

Finally, statutory revision of the APA niay be required, regardless of the Court's future handling of Bowen. ${ }^{323}$ A general agency statenient with the effect of law, if purely retroactive, is an "order" within the

322. See American Fed'n of Gov't Employees v. Nimmo, 536 F. Supp. 707, 715-16 (E.D. Va. 1982), aff'd on other grounds and vacated in part, 711 F.2d 28 (4th Cir. 1983).

323. The APA is a "procedural gap-filler" which relieves Congress of the need to provide for rulemaking procedures in substantive statutes. See 5 U.S.C. $\$ 559$ (1988). If Congress foresees the need for retroactive rules in particular cases, then it could provide expressly for the applicability of APA notice and comment procedures. However, as noted previously, see supra text accompanying note 322, not only is Congress' foresight limited, but the need for specific procedural provisions increases legislative burdens. At the same time, since the number of purely retroactive rules is probably small, amendment of the APA might be unwise or impractical if the sole reason is to cover such cases. However, if Justice Scalia's gloss on section 551(4) is ever accepted (even if his view of the APA as a limitation on substantive agency authority is not), then there is a stronger case for revising the APA.

One argument to avoid an APA amendment to cover purely retroactive rules would be that substantive grants of power enacted after 1946 "implicitly" amend the APA to extend its coverage. This largely fictional exercise is not preferable, however, to actual amendment and may not be possible in view of 5 U.S.C. $\S 559$ (1988). Section 559 states that "to modify" the APA a subsequent statute must do so "expressly." 
meaning of the APA and its adoption, amendment, and repeal are not significantly regulated by that statute. ${ }^{324}$ Although such regulations are rare, section $551(4)^{325}$ should perhaps be amended to include them withm the definition of "rule." The 1981 Model State Administrative Procedure Act ${ }^{326}$ and some states ${ }^{327}$ have achieved this result by excluding references to "future effect." 328 In this way, Congress would assure the general applicability of notice and comment procedures, whose value does not turn on the retroactive or prospective effect of a regulation. ${ }^{329}$ In the process of redrafting, however, Congress will have to consider the peculiar federal definition of "rule" in order to avoid leaving nothing for classification as an "order." 330

\section{CONCLUSION}

The good news from Bowen is that the Court did not seize the occasion to embrace the views of Justice Scalia with regard to the relevance of the Admimistrative Procedure Act to the question of statutory authority of an agency to adopt retroactive legislative rules. The bad news is that the Court invented a new clear statement principle that threatens to unduly limit agency discretion. However, there is reason to hope that the misstep can be remedied by the Court with relative ease. Canons of construction are, after all, generally aids to interpretation, which lack the legal weight of the legislative work product whose meaning they purport

324. See supra text accompanying notes 221-22.

325. 5 U.S.C. $\$ 551(4)$ (1988).

326. Uniform Law Commissioners' Revised Model State administrative ProceDURES ACT § 1-102(10), 14 U.L.A. 76 (1989 Supp.) (defines a "rule" as "the whole or a part of an agency statement of general applicability that implements, interprets, or prescribes (i) law or policy, or (ii) the organization, procedure, or practice requirements of an agency. The term includes the amendment, repeal, or suspension of an existing rule").

327. See, e.g., 12A ARIz. Rev. Stat. ANN. § 41-1001(12) (1990 Cum. Supp.) (stating that a rule "implements, interprets or prescribes law or policy").

328. For commentary on the omission, see, e.g., A. Bonfield, STATE AdMinistrative Rule MAKING 87-88 (1986) (stating that "future effect" language is unnecessary because no rule has any effect until it is legally binding); Auerbach, Administrative Rulemaking in Minnesota, 63 MINN. L. REv. 151, 157 (1979) (referring to the scenario in Addison and noting the occasional need to adopt a retroactive rule to protect those who relied on an earlier issued but invalid rule).

329. See Auerbach, supra note 328, at 157.

330. See supra note 209. Under the statute as re-drafted, statements of general applicability would be APA "rules." Agency statements of "particular" applicability may or may not be "rules" depending on, for example, an analogy to matters that are clearly APA rules or a reference to historical practice. The future effect of these "particular" pronouncements would be relevant, but not dispositive, to this classification. The Administrative Conference of the United States has endorsed an ABA recommendation to delete the reference to "particular" in section 551(4). See 3 REComMENDATIONS AND REPORTS OF THE ADMINISTRATIVE CONFERENCE OF THE UNITED STATES 59 (Jan. 1, 1973-June 30, 1974). The 1981 Model State Administrative Procedure Act does not refer to "particular" applicability or "future effect." See supra note 326. 
to identify. Accordingly, further reflection regarding the effects of their application may prompt a change of direction. The arguments and information marshalled in this Article, hopefully, will serve as a starting point for that reconsideration. ${ }^{331}$

331. On February 9, 1991, the Council of the Section on Administrative Law and Regulatory Practice adopted the following recommendation to be submitted to the ABA House of Delegates:

BE IT RESOLVED, that the American Bar Association recommends that:

1. Where a federal agency has statutory authority to adopt retroactive legislative rules which may impose new legal duties or liabilities, it should act retroactively only after determining that the need for retroactivity clearly outweighs the costs imposed and that retroactivity is otherwise fair in the circumstance. Moreover, where feasible, agencies should clearly specify in the preambles to such rules the statutory authority and the justification(s) for retroactivity.

2. In construing grants of rulemaking power where agency authority to adopt retroactive rules is unclear, federal courts should not apply a presumption which disfavors agency authority to adopt those retroactive rules that:

(a) protect persons who have relied on an agency rule which is subsequently declared invalid; or

(b) confer benefits without imposing retroactive legal duties or liabilities on members of the public.

3. The Administrative Procedure Act (5 U.S.C. $\$ \$ 551$ et seq.) should not be construed as excluding retroactive rules from its definition of "rule" in section 551(4). Instead, section 551(4) of the Act should be construed, or if necessary amended, to encompass rules that operate prospectively, retroactively or both, so that all such rules will remain subject to the constraints of the APA's rulemaking procedures. 